\title{
Insights into the Structure and Protein Composition of Moorella thermoacetica Spores Formed at Different Temperatures
}

\author{
Tiffany Malleck ${ }^{1,2}{ }^{\text {, Fatima Fekraoui }}{ }^{2}$ (D), Isabelle Bornard ${ }^{3}$, Céline Henry ${ }^{4}$, Eloi Haudebourg ${ }^{4}$, Stella Planchon ${ }^{2, *}$ \\ and Véronique Broussolle ${ }^{1, *}$ \\ 1 INRAE, Avignon Université, UMR SQPOV, F-84000 Avignon, France; tiffany.malleck@outlook.fr \\ 2 Unité EMaiRIT'S, CTCPA, F-84911 Avignon, France; fatima.fekraoui@agrosupdijon.fr \\ 3 INRAE, Pathologie Végétale, F-84143 Avignon, France; isabelle.bornard@inrae.fr \\ 4 PAPPSO, Micalis Institute, INRAE, AgroParisTech, Université Paris-Saclay, F-78352 Jouy-en-Josas, France; \\ celine.henry@inrae.fr (C.H.); eloi.haudebourg@gmail.com (E.H.) \\ * Correspondence: splanchon@ctcpa.org (S.P.); veronique.broussolle@inrae.fr (V.B.); \\ Tel.: +33-04908-43246 (S.P.); +33-04327-22518 (V.B.)
}

check for

updates

Citation: Malleck, T.; Fekraoui, F.

Bornard, I.; Henry, C.; Haudebourg,

E.; Planchon, S.; Broussolle, V.

Insights into the Structure and

Protein Composition of Moorella

thermoacetica Spores Formed at

Different Temperatures. Int. J. Mol.

Sci. 2022, 23, 550. https://doi.org/

$10.3390 /$ ijms 23010550

Academic Editors: Stanley Brul,

Peter Setlow and Ezio Ricca

Received: 29 September 2021

Accepted: 23 December 2021

Published: 4 January 2022

Publisher's Note: MDPI stays neutral with regard to jurisdictional claims in published maps and institutional affiliations.

Copyright: (C) 2022 by the authors. Licensee MDPI, Basel, Switzerland. This article is an open access article distributed under the terms and conditions of the Creative Commons Attribution (CC BY) license (https:// creativecommons.org/licenses/by/ $4.0 /)$.

\begin{abstract}
The bacterium Moorella thermoacetica produces the most heat-resistant spores of any spoilagecausing microorganism known in the food industry. Previous work by our group revealed that the resistance of these spores to wet heat and biocides was lower when spores were produced at a lower temperature than the optimal temperature. Here, we used electron microcopy to characterize the ultrastructure of the coat of the spores formed at different sporulation temperatures; we found that spores produced at $55^{\circ} \mathrm{C}$ mainly exhibited a lamellar inner coat tightly associated with a diffuse outer coat, while spores produced at $45^{\circ} \mathrm{C}$ showed an inner and an outer coat separated by a less electrondense zone. Moreover, misarranged coat structures were more frequently observed when spores were produced at the lower temperature. We then analyzed the proteome of the spores obtained at either $45^{\circ} \mathrm{C}$ or $55^{\circ} \mathrm{C}$ with respect to proteins putatively involved in the spore coat, exosporium, or in spore resistance. Some putative spore coat proteins, such as CotSA, were only identified in spores produced at $55^{\circ} \mathrm{C}$; other putative exosporium and coat proteins were significantly less abundant in spores produced at $45^{\circ} \mathrm{C}$. Altogether, our results suggest that sporulation temperature affects the structure and protein composition of $M$. thermoacetica spores.
\end{abstract}

Keywords: electron microscopy; in silico analysis; proteomics; coat; exosporium

\section{Introduction}

Endosporulation is an ancient mechanism, first appearing about 2 billion years ago, that allows Gram-positive bacteria to adapt to harsh environmental conditions. Bacterial spores are much more resistant than vegetative cells and are considered to be dormant forms, providing sporulated bacteria the ability to persist in the environment for several years [1].

The structure of a spore differs greatly from that of vegetative cells, with the chromosome in a dehydrated core, surrounded by several concentric layers: the inner forespore membrane, the germ cell wall, the cortex, the outer forespore membrane, the coat layers, and an outer layer structure, called the crust in Bacillus subtilis and the exosporium in other species of Bacillus and Clostridium [2]. This particular structure has been shown to provide the spores some ability to adhere to biotic and abiotic surfaces, as well as protection against various types of stress [1,2].

Dehydration of the spore core is a major factor in spores' resistance to wet heat, which increases as the core water content decreases $[3,4]$. The cortex appears to play an important role in reducing the water content of the spore during spore formation, together with the accumulation of dipicolinic acid (DPA), a specific component of spores that complexes with 
$\mathrm{Ca}^{2+}$ late in sporulation and displaces core water $[5,6]$. The two spore maturation proteins SpmA and SpmB have been shown to play a major role in spore core dehydration, as spores lacking these proteins are characterized by higher core hydration $[3,4]$. Furthermore, the small acid-soluble proteins (SASPs) $\alpha / \beta$, which saturate and stabilize spore DNA, contribute to spores' resistance to UV-C and dry heat, as well as to genotoxic compounds such as nitrous acid and formaldehyde [7-10]. The external layers formed by the proteinaceous coat are associated with protection against lysozyme and oxidizing agents [11-14].

These spore resistance properties, as well as spore structure and composition, depend strongly on the conditions of sporulation. Sporulation temperature is known to alter spores' resistance to various stress, such as wet heat and biocides [15-21], and can have significant effects, together with medium composition, on spore structure and composition, such as fatty acid content and protein content [15-17,22-24].

The resistance of bacterial spores to extreme conditions represents a particular challenge in the food industry, where they can be a major cause of food spoilage. Moorella thermoacetica is a significant problem in the canned food industry because its spores are the most heat resistant of any so far retrieved, with $D$ values (decimal reduction times) up to $110 \mathrm{~min}$ at $121^{\circ} \mathrm{C}[20,25]$. Formerly known as Clostridium thermoaceticum, $M$. thermoacetica is a strictly anaerobic and thermophilic spore-forming bacterium [26]. Recently, we showed that $M$. thermoacetica spores produced at the lowest temperature at which growth is possible (i.e., $45^{\circ} \mathrm{C}$ ) were less heat resistant and less resistant to biocides than spores produced at the optimal growth temperature (i.e., $55^{\circ} \mathrm{C}$ ) [27].

To date, $M$. thermoacetica spore structure has been only poorly described and its spore protein composition remains unknown. Here, we aimed to determine if $M$. thermoacetica spores produced at two different temperatures, $45^{\circ} \mathrm{C}$ and $55^{\circ} \mathrm{C}$, exhibited differences in terms of structure and protein composition. To achieve this, the surface structure and ultrastructure of spores produced at these two temperatures were observed by scanning electron microscopy (SEM) and transmission electron microscopy (TEM), respectively. Spore protein composition was then further analyzed using an LC-MS/MS label-free approach.

Using this approach, we are able to report that the coat ultrastructure of $M$. thermoacetica spores and the protein composition of spore layers are modified by suboptimal sporulation conditions.

\section{Results}

\subsection{Spore Surface Structure}

Spores of M. thermoacetica ATCC 39073 were produced on agar plates at either optimal growth temperature $\left(55^{\circ} \mathrm{C}\right)$ or suboptimal temperature $\left(45^{\circ} \mathrm{C}\right)$, with four batches of each. They were then observed by SEM ( $n=78$ and $n=73$ spores, respectively). Spores produced at $55^{\circ} \mathrm{C}$ appeared spherical and highly heterogeneous in terms of size (Figure 1A).
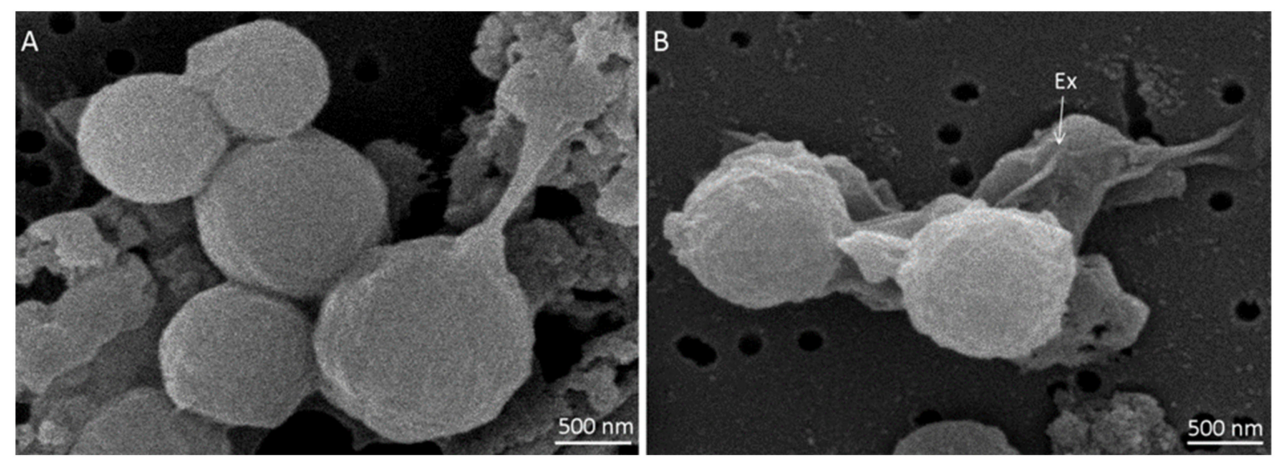

Figure 1. Spores of Moorella thermoacetica strain ATCC 39073, produced on agar plates at $55^{\circ} \mathrm{C}$ and observed by scanning electron microscopy: (A) spores of different sizes with a smooth surface; (B) two spores enveloped by a large, loose structure corresponding to the exosporium (Ex), as indicated by the white arrow. 
Indeed, spore diameter ranged from 0.87 to $1.65 \mu \mathrm{m}$, with an average size of $1.2 \pm 0.1 \mu \mathrm{m}$. Spores produced at $45^{\circ} \mathrm{C}$ exhibited the same morphology as at $55^{\circ} \mathrm{C}$ (Figure S1), but were significantly smaller $(p<0.05)$, with a diameter ranging from 0.85 to $1.46 \mu \mathrm{m}$ and an average size of $1.1 \pm 0.1 \mu \mathrm{m}$ (Tables S1 and S2). A large, loose structure was observed surrounding the spores (Figure 1B). This structure, which is assumed to be the exosporium, was more easily distinguished when spores were formed at $45^{\circ} \mathrm{C}$. The spore surface structure, as observed by SEM, did not seem to differ based on sporulation temperature.

\subsection{Spore Ultrastructure}

To determine if the spore ultrastructure is affected by sporulation temperature, we used TEM to describe $M$. thermoacetica spores produced at $55^{\circ} \mathrm{C}$ or $45^{\circ} \mathrm{C}$ (four independent batches; $n=38$ and $n=45$ spores, respectively). Spores produced at $55^{\circ} \mathrm{C}$ were characterized, from the inner to the outer structure, by the presence of a core, a cortex and a coat, all surrounded by a large, loose exosporium, which appeared to be separated from the coat by an interspace (Figure 2A). The exosporium was observed, regardless of the sporulation temperature. The global structure of spores produced at $45^{\circ} \mathrm{C}$ was very similar (Figure 2B); however, the border between the core and the cortex layer was more easily observed than in spores produced at $55^{\circ} \mathrm{C}$ (Figure 2A,B).
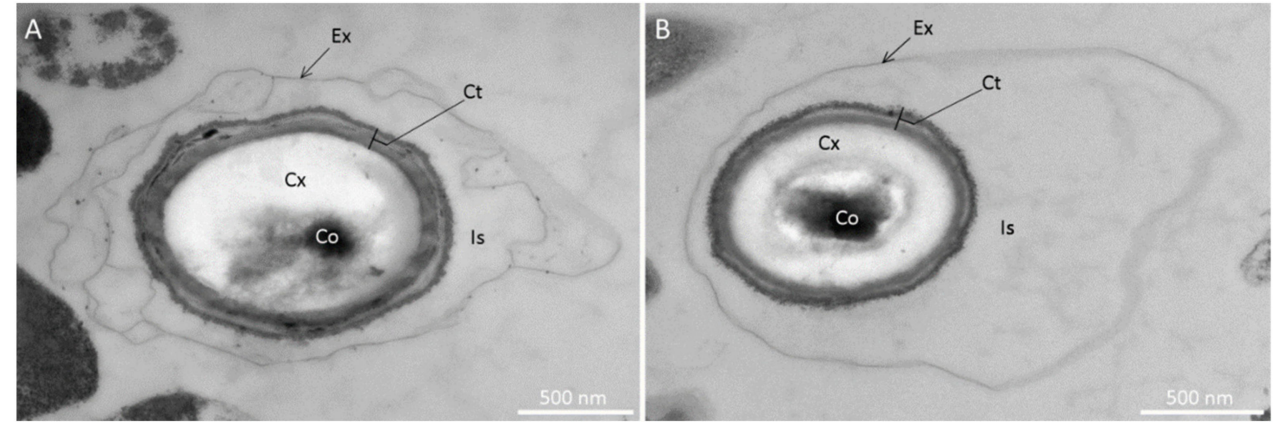

Figure 2. Ultrastructure of spores of Moorella thermoacetica ATCC 39073 produced at $55{ }^{\circ} \mathrm{C}(\mathrm{A})$ or $45^{\circ} \mathrm{C}(\mathbf{B})$ on agar plates, observed by transmission electron microscopy. Ex: exosporium; Is: interspace; $\mathrm{Ct}$ : coat; $\mathrm{Cx}$ : cortex; Co: core.

Overall, two types of spores were observed: (1) spores with a lamellar inner coat in direct contact with a thinner, electron-dense and diffuse outer coat layer (Figure 3A), mainly observed in spores produced at $55{ }^{\circ} \mathrm{C}$ ( 30 spores out of the 45 observed); and (2) spores exhibiting the same inner and outer coat layers, which seemed to be separated by a less electron-dense zone (Figure 3B), mainly observed in spores produced at $45^{\circ} \mathrm{C}$ ( 34 spores out of the 39 observed). Moreover, we sometimes observed the presence of highly electrondense material accumulated in the inner spore coat layer, either surrounding the spore or present as small deposits (Figure 3C).

These structures were more frequently observed in spores produced at $55^{\circ} \mathrm{C}$ than at $45^{\circ} \mathrm{C}$ (18 and 2 spores, respectively). Moreover, some spores exhibited misarranged coats, which were loosely attached to the spore surface at some points, with protuberances in the outer coat (Figure 3E) or the outer coat and part of the inner coat partially detached from the spore surface (Figure 3D). These misarrangements were more frequently observed in spores produced at $45^{\circ} \mathrm{C}$ than at $55^{\circ} \mathrm{C}$ ( 17 out of the 39 observed spores and 9 out of 45 spores, respectively). 


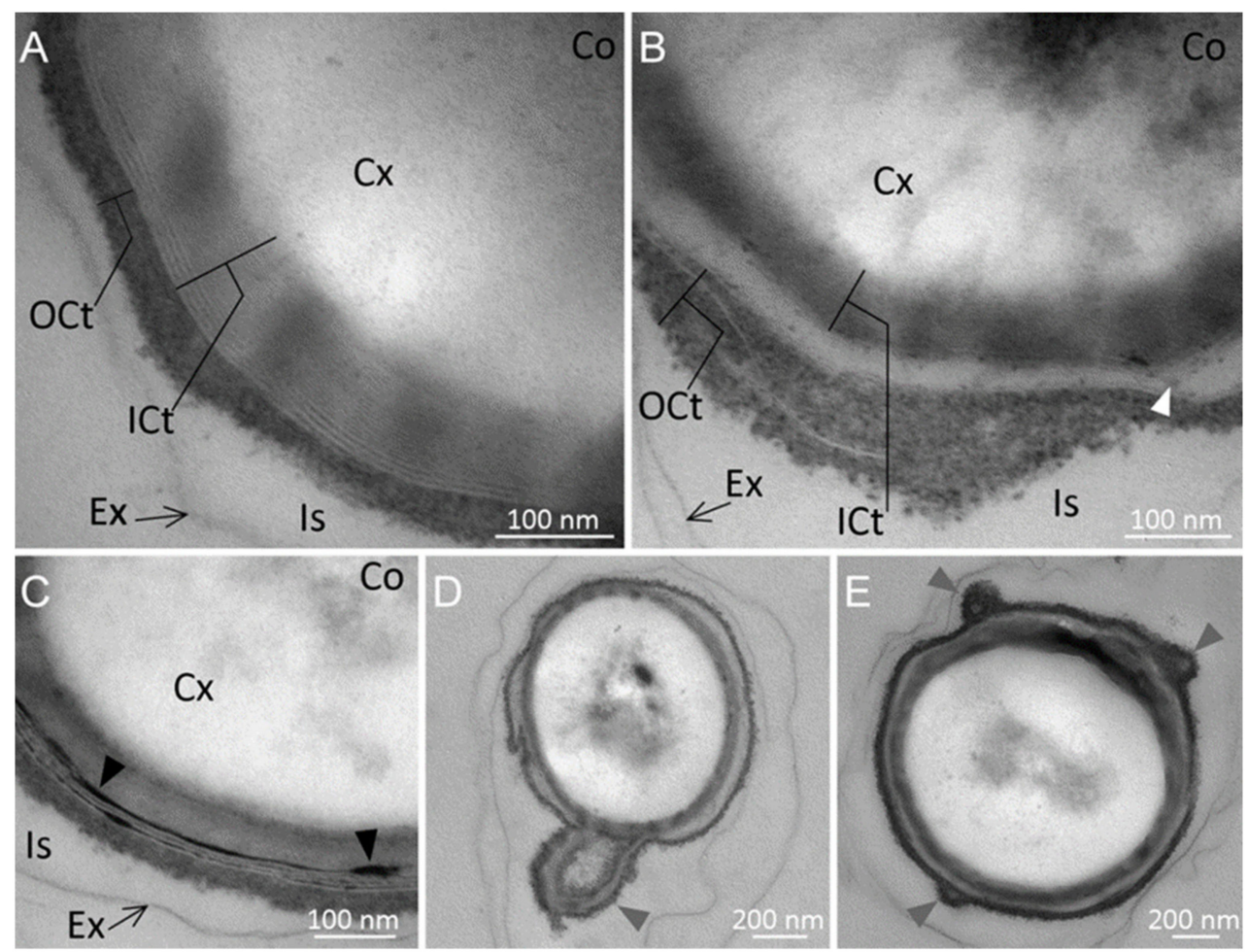

Figure 3. Coat structure of Moorella thermoacetica ATCC 39073 spores produced at $55{ }^{\circ} \mathrm{C}$ (panels (A,C) and at $45^{\circ} \mathrm{C}$ (panels $(\mathbf{B}, \mathbf{D}, \mathbf{E})$ ). Two types of spores were obtained under both sporulation conditions (panels $(\mathbf{A}, \mathbf{B})$ ). The spore coat in panel $(\mathbf{A})$ is made of an inner lamellar layer in direct contact with a dense, diffuse outer layer, while in panel (B) the spore inner and outer coats are separated from each other by a less electron-dense zone (white arrow). Panel (C) shows electron-dense deposits often observed in the inner spore coat of spores produced at $55^{\circ} \mathrm{C}$ (black arrows). Outer and inner spore coat misarrangements are shown in panels $(\mathbf{D}, \mathbf{E})$ (gray arrows). Ex: exosporium; Is: interspace; OCt: outercoat; ICt: innercoat; Cx: cortex; Co: core.

\subsection{Identification of Spore Proteins in Moorella thermoacetica ATCC 39073}

To identify spore-associated proteins in the genome of $M$. thermoacetica ATCC 39073 [28], we performed a BLAST search using amino-acid sequences of spore proteins, identified in previous proteomic or genomic analysis on Clostridium difficile, Clostridium perfringens, Bacillus subtilis, Bacillus cereus, and Bacillus anthracis (see references in Table 1), belonging to the Clostridiales and Bacillales orders of the Firmicutes [29]. We mainly focused on proteins from the coat and exosporium layers, as well as proteins described as being involved in spore resistance properties. We searched for the presence/absence of about 200 spore-associated proteins (Tables 1 and S2). From this, a total of 62 putative orthologs was identified in the M. thermoacetica genome (Table 1), with 51 of those corresponding to proteins known to be localized in the coat, exosporium, or spore membranes in other spore-forming bacteria.

Among the proteins associated with the exosporium, we identified orthologs of two rubrerythrins from C. difficile, as well as orthologs of CD0116, CD0117, and CD0118, which might play a role in oxidative stress resistance [30,31]. The moth_2167 gene was found to encode a putative alanine racemase and two putative arginases were also identified. Among the proteins associated with the coat, the moth_1319 gene appeared to encode an ortholog of the morphogenetic protein SpoIVA, which is necessary for proper assembly of the inner coat of $B$. subtilis. Among the structural coat proteins, we found orthologs of the inner coat layer proteins CotJB and $\operatorname{CotJC}$, a putative CotSA ortholog, and two coat F-containing proteins. One of these latter proteins, encoded by the moth_1782 gene, was identified according to genome annotation and a blastP search against Clostridium proteins confirmed that this protein likely corresponds to an unidentified coat protein. 
The second coat F-containing protein, encoded by the moth_2016 gene, is homologous to the uncharacterized protein YhcQ of $B$. subtilis. In addition, we found an ortholog of a YabG protease that is associated with spore coat protein modification [32]. Among the spore coat proteins, we also identified a superoxide dismutase protein, which is thought to play a potential role in spore resistance to hydrogen peroxide [31]. Other putative spore coat proteins included the spore cortex-lytic hydrolases $\mathrm{YaaH}, \mathrm{YdhD}$, and $\mathrm{YhxC}$, for which an additional role in B. subtilis competence has recently been reported [33]; and several proteins, such as $\mathrm{YkvN}$, whose roles have not yet been described.

Table 1. Spore-related proteins identified in Moorella thermoacetica ATCC 39073.

\begin{tabular}{|c|c|c|c|c|c|c|}
\hline $\begin{array}{c}\text { Moorella } \\
\text { thermoacetica } \\
\text { ATCC } 39073 \\
\text { LocusS }^{\text {a }}\end{array}$ & Protein $\mathrm{ID}^{\mathrm{b}}$ & $\begin{array}{l}\text { M. thermoacetica } \\
\text { Protein Identification }\end{array}$ & $\begin{array}{c}\text { Putative } \\
\text { Protein Name }^{c}\end{array}$ & $\begin{array}{l}\text { Hypothetical } \\
\text { Function }^{d}\end{array}$ & $\begin{array}{c}\text { Putative } \\
\text { Localization }\end{array}$ & $\begin{array}{c}\text { ProteinsS of } \\
\mathrm{Bs} / \mathrm{Bc} / \mathrm{Ba} / \mathrm{Cd} / \mathrm{Cp}^{\mathrm{c}, \mathrm{d}}\end{array}$ \\
\hline moth_1518 & Q2RIB2 & $\begin{array}{l}\text { Ferredoxin-NADP(+) } \\
\text { reductase subunit alpha }\end{array}$ & - & $\mathrm{Nd}^{\mathrm{e}}$ & Exosporium & CD1536 \\
\hline $\begin{array}{l}\text { moth_1286 } \\
\text { moth_1879 }\end{array}$ & Q2RIY9 Q2RHB0 & Rubrerythrin & Rbr & $\begin{array}{l}\text { Likely to play a role in } \\
\text { spore resistance }\end{array}$ & Exosporium & CD0825 CD1524 \\
\hline moth_0602 & Q2RKV7 & Uncharacterized protein & - & nd & Exosporium & CD2434 \\
\hline $\begin{array}{l}\text { moth_1747 } \\
\text { moth_1815 }\end{array}$ & Q2RHP1 Q2RHH4 & $\begin{array}{c}\text { Uncharacterized } \\
\text { protein/Agmatinase }\end{array}$ & Arginase & nd & Exosporium & $\begin{array}{l}\text { BAS0155 } \\
\text { BAS2260 }\end{array}$ \\
\hline moth_2167 & Q2RGI3 & Alanine racemase & Alr & Spore protection & Exosporium & $\begin{array}{l}\text { BSU17640 } \\
\text { BAS0238 }\end{array}$ \\
\hline moth_1405 & Q2RIM1 & Nucleoside recognition & FeoB & nd & Exosporium & CD1517 \\
\hline moth_1683 & Q2RHV4 & $\begin{array}{l}\text { Cation diffusion } \\
\text { facilitator family } \\
\text { transporter }\end{array}$ & - & nd & Exosporium & CD0902 \\
\hline moth_0034 & Q2RMG5 & 2-oxoglutarate synthase & - & nd & Exosporium & CD0117 \\
\hline moth_0033 & Q2RMG6 & $\begin{array}{c}\text { Pyruvate } \\
\text { flavodoxin/ferredoxin } \\
\text { oxidoreductase-like } \\
\text { protein }\end{array}$ & - & nd & Exosporium & CD0116 \\
\hline moth_0035 & Q2RMG4 & $\begin{array}{l}\text { 2-oxoacid: acceptor } \\
\text { oxidoreductase, gamma } \\
\text { subunit, pyruvate/2- } \\
\text { ketoisovalerate }\end{array}$ & - & nd & Exosporium & CD0118 \\
\hline moth_0266 & Q2RLT8 & Enolase & Eno & nd & Coat/exosporium & CD3170 \\
\hline moth_0837 & Q2RK85 & $\begin{array}{l}\text { Stage V sporulation } \\
\text { protein } D\end{array}$ & SpoVD & $\begin{array}{l}\text { mother-cell specific } \\
\text { penicillin-binding } \\
\text { protein (spore cortex) }\end{array}$ & Coat/exosporium & ВС3915 \\
\hline moth_2301 & Q2RG51 & $\begin{array}{l}\text { Kynurenine } \\
\text { formamidase }\end{array}$ & - & $\begin{array}{l}\text { Metal-dependent } \\
\text { hydrolase }\end{array}$ & Coat/exosporium & ВC0395 \\
\hline moth_0739 & Q2RKI2 & $\begin{array}{l}\text { Polysaccharide } \\
\text { deacetylase }\end{array}$ & $\begin{array}{l}\text { YlxY or Pda or } \\
\text { PdaB }\end{array}$ & $\begin{array}{l}\text { PdaA/PdaB:spore } \\
\text { cortex peptidoglycan } \\
\text { synthesis }\end{array}$ & Coat/exosporium & CD2598 \\
\hline moth_1414 & Y1414_MOOTA & $\begin{array}{l}\text { UPF0597 protein } \\
\text { moth_1414 }\end{array}$ & - & nd & Coat/exosporium & CD630 \\
\hline moth_0738 & Q2RKI3 & $\begin{array}{l}\text { Peptidase M1, } \\
\text { membrane alanine } \\
\text { aminopeptidase }\end{array}$ & - & nd & Coat/exosporium & CD3652 \\
\hline moth_1693 & Q2RHU4 & $\begin{array}{l}\text { Protein translocase } \\
\text { subunit YajC }\end{array}$ & YajC & nd & Coat/exosporium & BC4410 \\
\hline moth_1319 & Q2RIV7 & $\begin{array}{l}\text { Stage IV sporulation } \\
\text { protein A }\end{array}$ & SpoIVA & $\begin{array}{l}\text { Anchors the spore } \\
\text { coat to the spore } \\
\text { surface via SpoVM }\end{array}$ & $\begin{array}{l}\text { Spore coat } \\
\text { basement }\end{array}$ & $\begin{array}{l}\text { BSU22800 BC1509 } \\
\text { CD2629 }\end{array}$ \\
\hline moth_1782 ${ }^{\mathrm{f}}$ & Q2RHK6 & CoatF & - & nd & Coat & - \\
\hline moth_1059 & Q2RJL6 & $\begin{array}{l}\text { Peptidase M16-like } \\
\text { protein }\end{array}$ & $Y m x G$ & nd & Coat & ВС3786 \\
\hline moth_1391 & Q2RIN5 & $\begin{array}{l}\text { Spore coat peptide } \\
\text { assembly protein CotJB }\end{array}$ & $\operatorname{Cot} J B$ & nd & Inner coat & $\begin{array}{l}\text { BSU06900 BC0822 } \\
\text { CD630 }\end{array}$ \\
\hline moth_1392 & Q2RIN4 & $\begin{array}{l}\text { Manganese containing } \\
\text { catalase }\end{array}$ & $\operatorname{Cot} \mathrm{C}$ & $\begin{array}{l}\text { May protect against } \\
\text { oxydative stress }\end{array}$ & Inner coat & $\begin{array}{l}\text { BSU06910 BC0821 } \\
\text { CD0598 CD2401 } \\
\text { CPR0934 }\end{array}$ \\
\hline
\end{tabular}


Table 1. Cont.

\begin{tabular}{|c|c|c|c|c|c|c|}
\hline $\begin{array}{c}\text { Moorella } \\
\text { thermoacetica } \\
\text { ATCC } 39073 \\
\text { LocusS }^{\text {a }}\end{array}$ & Protein ID ${ }^{b}$ & $\begin{array}{l}\text { M. thermoacetica } \\
\text { Protein Identification }\end{array}$ & $\begin{array}{c}\text { Putative } \\
\text { Protein Name }\end{array}$ & $\begin{array}{l}\text { Hypothetical } \\
\text { Function }{ }^{d}\end{array}$ & $\begin{array}{c}\text { Putative } \\
\text { Localization }\end{array}$ & $\begin{array}{c}\text { ProteinsS of } \\
\mathrm{Bs} / \mathrm{Bc} / \mathrm{Ba} / \mathrm{Cd} / \mathrm{Cp}^{\mathrm{c}, \mathrm{d}}\end{array}$ \\
\hline moth_0257 & Q2RLU7 & $\begin{array}{c}\text { HAD-superfamily } \\
\text { hydrolase subfamily IIB }\end{array}$ & YhaX & Protection of the spore & $\begin{array}{c}\text { Spore coat } \\
\text { basement }\end{array}$ & BSU09830 \\
\hline moth_1069 & Q2RJK6 & Ribonuclease J & RnjA & RNA processing & Coat & BC3977 \\
\hline moth_2016 & Q2RGX7 & CoatF-like protein & YhcQ & nd & Coat & BSU30910 \\
\hline moth_1365 & Q2RIR1 & Coat protein SA & CotSA & Spore resistance & Coat & BSU30910 \\
\hline moth_1126 & Q2RJE9 & $\begin{array}{c}\text { Amino acid ABC } \\
\text { transporter } \\
\text { substrate-binding } \\
\text { protein, PAAT family }\end{array}$ & TcyA (YckK) & Cystine uptake & Coat & BSU03610 \\
\hline moth_1016 & Q2RJQ9 & $\begin{array}{l}\text { Spore coat protein } \\
\text { manganese catalase }\end{array}$ & CotG & nd & Coat & CD1567 \\
\hline moth_1693 & Q2RHU4 & $\begin{array}{l}\text { Protein translocase } \\
\text { subunit YajC }\end{array}$ & YajC/YrbF & nd & $\begin{array}{c}\text { Inner } \\
\text { membrane/coat }\end{array}$ & BSU27700 \\
\hline moth_1916 & Q2RH73 & Superoxide dismutase & SodF/SodA & $\begin{array}{l}\text { Detoxication of } \\
\text { oxygen radicals }\end{array}$ & Coat & $\begin{array}{l}\text { BSU19330 BC1468 } \\
\text { CD1631 }\end{array}$ \\
\hline moth_0056 & Q2RME4 & $\begin{array}{l}\text { Sporulation-specific } \\
\text { protease }\end{array}$ & YabG & $\begin{array}{l}\text { Modification of spore } \\
\text { coat proteins }\end{array}$ & Coat & $\begin{array}{l}\text { BSU00430 BC0047 } \\
\text { CD3569 CPR2191 }\end{array}$ \\
\hline moth_0373 & Q2RLI2 & $\begin{array}{l}\text { Putative transcriptional } \\
\text { regulator }\end{array}$ & YkvN & $\begin{array}{l}\text { MarR/DUF24 family } \\
\text { transcription regulator }\end{array}$ & Coat & BSU13760 \\
\hline moth_0426 & Q2RLD2 & $\begin{array}{l}\text { Short-chain dehydroge- } \\
\text { nase/reductase }\end{array}$ & YhxC & $\begin{array}{l}\text { Similar to alcohol } \\
\text { dehydrogenase }\end{array}$ & Coat & BSU10400 \\
\hline moth_0517 & Q2RL42 & $\begin{array}{l}\mathrm{N} \text {-acetylmuramoyl-L- } \\
\text { alanine amidase }\end{array}$ & - & $\begin{array}{l}\text { Involved in } \\
\text { germination }\end{array}$ & Coat & BC2207 \\
\hline moth_0527 & Q2RL32 & Trigger Factor & - & nd & Coat & BC 4480 \\
\hline moth_0063 & Q2RMD7 & $\begin{array}{l}\text { Glycoside hydrolase, } \\
\text { family } 18\end{array}$ & YaaH ot YdhD & $\begin{array}{l}\text { YaaH: spore } \\
\text { germination cortex } \\
\text { lytic enzyme } \\
\text { YdhD: spore coat } \\
\text { peptidoglycan } \\
\text { hydrolase }\end{array}$ & $\begin{array}{l}\text { Inner coat }(\mathrm{YaaH}) \\
\text { Coat }(\mathrm{YdhD})\end{array}$ & $\begin{array}{c}\text { BSU01160/BSU05710 } \\
\text { BC3607 }\end{array}$ \\
\hline moth_0088 & Q2RMB2 & Uncharacterized protein & YabP & $\begin{array}{l}\text { Required for } \\
\text { sporulation at a late } \\
\text { stage }\end{array}$ & Outer membrane & $\begin{array}{l}\text { BSU00600 BC0063 } \\
\text { CPR2486 }\end{array}$ \\
\hline $\begin{array}{l}\text { moth_1357g } \\
\text { moth_1058 }\end{array}$ & $\begin{array}{l}\text { Q2RIR9 } \\
\text { Q2RJL7 }\end{array}$ & $\begin{array}{l}\text { Serine-type D-Ala-D-Ala } \\
\text { carboxypeptidase }\end{array}$ & $\mathrm{DacB}$ & $\begin{array}{l}\text { Sporulation-specific } \\
\text { carboxypeptidase } \\
\text { involved in spore } \\
\text { cortex peptidoglycane } \\
\text { cross-linking }\end{array}$ & Cortex & BSU23190 CPR1770 \\
\hline moth_0201 & Q2RM03 & $\begin{array}{l}\text { Propeptide, PepSY amd } \\
\text { peptidase M4 }\end{array}$ & YpeB & $\begin{array}{l}\text { Germination protein, } \\
\text { essential for SleB } \\
\text { assembly in spores }\end{array}$ & Inner membrane & BSU22920 BC2752 \\
\hline moth_1499 & Q2RID1 & $\begin{array}{l}\text { Serine-type D-Ala-D-Ala } \\
\text { carboxypeptidase }\end{array}$ & $\mathrm{DacF}$ & $\begin{array}{l}\text { Penicillin-binding } \\
\text { protein I }\end{array}$ & Inner membrane & $\begin{array}{l}\text { BSU23480 BC4075 } \\
\text { CD1291 CPR1775 }\end{array}$ \\
\hline moth_0887 & Q2RK35 & ATPase, E1-E2 type & AtcL & $\begin{array}{l}\text { Similar to the E. coli } \\
\text { magnesium } \\
\text { transporter }\end{array}$ & Inner membrane & BSU15650 \\
\hline $\begin{array}{l}\text { moth_0734 } \\
\text { moth_0054 } \\
\text { moth_0202 }\end{array}$ & $\begin{array}{l}\text { Q2RKI7 } \\
\text { Q2RME6 } \\
\text { Q2RM02 }\end{array}$ & Cell wall hydrolase & SleB & $\begin{array}{l}\text { Spore cortex-lytic } \\
\text { enzyme involved in } \\
\text { germination }\end{array}$ & $\begin{array}{l}\text { Outer surface of the } \\
\text { inner spore } \\
\text { membrane }\end{array}$ & BSU13930 BC2753 \\
\hline moth_1358 & Q2RIR8 & Uncharacterized protein & GerW/YtfJ & Germination protein & Inner membrane & $\begin{array}{c}\text { BSU29500 } \\
\text { BC4640/BC2095 }\end{array}$ \\
\hline moth_0926 & Q2RJZ6 & Germination protease & Gpr & Degradation of SASPs & $\begin{array}{c}\text { Inner } \\
\text { membrane/core }\end{array}$ & $\begin{array}{l}\text { BSU25540 BC4319 } \\
\text { CPR2013 }\end{array}$ \\
\hline $\begin{array}{l}\text { moth_2417 } \\
\text { moth_0736 }\end{array}$ & $\begin{array}{l}\text { Q2RFU0 } \\
\text { Q2RKI5 }\end{array}$ & $\begin{array}{l}\text { Peptidase S1 and S6, } \\
\text { chymotrypsin/Hap }\end{array}$ & YyxA & $\begin{array}{c}\text { Similar to quality } \\
\text { control membrane } \\
\text { serine protease HtrA }\end{array}$ & Inner membrane & BSU40360 \\
\hline moth_0925 & Q2RJZ7 & $\begin{array}{l}\text { Small acid-soluble spore } \\
\text { protein, alpha/beta type }\end{array}$ & SspA & $\begin{array}{l}\text { Protection of spore } \\
\text { DNA }\end{array}$ & Core & BSU29750 CD2688 \\
\hline
\end{tabular}


Table 1. Cont.

\begin{tabular}{|c|c|c|c|c|c|c|}
\hline $\begin{array}{c}\text { Moorella } \\
\text { thermoacetica } \\
\text { ATCC } 39073 \\
\text { LocusS }^{\text {a }}\end{array}$ & Protein ID ${ }^{b}$ & $\begin{array}{l}\text { M. thermoacetica } \\
\text { Protein Identification }\end{array}$ & $\begin{array}{c}\text { Putative } \\
\text { Protein Name }^{c}\end{array}$ & $\begin{array}{l}\text { Hypothetical } \\
\text { Function }{ }^{d}\end{array}$ & $\begin{array}{c}\text { Putative } \\
\text { Localization }\end{array}$ & $\begin{array}{c}\text { ProteinsS of } \\
\mathrm{Bs} / \mathrm{Bc} / \mathrm{Ba} / \mathrm{Cd} / \mathrm{Cp}^{\mathrm{c}, \mathrm{d}}\end{array}$ \\
\hline moth_0806 & Q2RKB5 & $\begin{array}{l}\text { Small, acid-soluble spore } \\
\text { protein, alpha/beta } \\
\text { family }\end{array}$ & SspF & $\begin{array}{c}\text { Protection of the spore } \\
\text { DNA }\end{array}$ & Core & BSU24210 \\
\hline moth_1875 & Q2RHB4 & $\begin{array}{l}\text { Small, acid-soluble spore } \\
\text { protein }\end{array}$ & SASP & $\begin{array}{l}\text { Small, acid-soluble } \\
\text { spore protein }\end{array}$ & Core & CPR1870 \\
\hline moth_2056 & Q2RGT7 & $\begin{array}{c}\text { NADH:flavin } \\
\text { oxidoreductase/NADH } \\
\text { oxidase }\end{array}$ & YqiG & nd & nd & BSU24210 \\
\hline moth_1272 & Q2RJ03 & $\begin{array}{l}\mathrm{N} \text {-acetylmuramoyl-L- } \\
\text { alanine } \\
\text { amidase }\end{array}$ & CwlC & $\begin{array}{l}\text { Sporulation-specific } \\
\text { N-acetylmuramoyl_L- } \\
\text { alanine } \\
\text { amidase }\end{array}$ & nd & BSU17410 \\
\hline moth_1828 & Q2RHG1 & Uncharacterized protein & YckD & nd & nd & BSU03400 \\
\hline moth_1059 & Q2RJL6 & $\begin{array}{l}\text { Peptidase M16-like } \\
\text { protein }\end{array}$ & YmxG & $\begin{array}{c}\text { Control of proteolytic } \\
\text { activity }\end{array}$ & nd & BSU16710 \\
\hline moth_1356 & Q2RIS0 & Nucleoside recognition & SpmA & $\begin{array}{l}\text { Spore maturation } \\
\text { protein, spore core } \\
\text { dehydration, involved } \\
\text { in germination }\end{array}$ & nd & BSU23180 BC1470 \\
\hline moth_1355 & Q2RIS1 & Nucleoside recognition & SpmB & $\begin{array}{l}\text { Spore maturation } \\
\text { protein, spore core } \\
\text { dehydration, involved } \\
\text { in germination }\end{array}$ & nd & BSU23170 BC1471 \\
\hline moth_1064 & Q2RJL1 & $\begin{array}{c}\text { Alanine } \\
\text { dehydrogenase/PNT- } \\
\text { like } \\
\text { protein }\end{array}$ & SpoVFA & $\begin{array}{c}\text { Dipicolinate synthase } \\
\text { (subunit A) }\end{array}$ & nd & BSU16730 ВC3801 \\
\hline moth_1065 & Q2RJL0 & Flavoprotein & SpoVFB & $\begin{array}{c}\text { Dipicolinate synthase } \\
\text { (subunit B) }\end{array}$ & nd & BSU16740 BC3800 \\
\hline
\end{tabular}

${ }^{a}$ Moorella thermoacetica ATCC 39073 database [28]; ${ }^{b}$ Information from the UniProtKB database (http:/ /www. uniprot.org, accessed on 29 September 2021); ${ }^{\mathrm{C}}$ All proteins were identified by Blast-P from the spore coat and/or exosporium of Bacillus subtilis 168 (Bs, BSU), B. cereus ATCC 14579 (Bc, BC), B. anthracis Sterne (Ba, BAS), C. difficile 630 (Cd, CD), and C. perfringens (Cp, CPR); ${ }^{\mathrm{d}}$ Data obtained from Abhyankar et al., 2011 [34]; Abhyankar et al., 2013 [35]; Paredes-Sabja et al., 2014 [36]; Diaz-Gonzalez et al., 2015 [37]; Stewart, 2015 [38]; Abhyankar et al., 2016 [23]; Subtiwiki (http:/ / subtiwiki.uni-goettingen.de/, accessed on 29 September 2021); ${ }^{\text {e }}$ nd: protein function and/or localization not determined; ${ }^{\mathrm{f}}$ Protein annotated as Coat $\mathrm{F}$ protein in the $M$. thermoacetica genome but with spore coat proteins of $B$. subtilis; ${ }^{g}$ Amino acid sequences encoded by moth_1058 and moth_1357 are highly similar The $d a c B$ gene is described as being in an operon with the $s p m A$ and spmB genes. Thus, the moth_1357 locus more likely encodes DacB.

In this in silico analysis, we also identified proteins that are not described as coat or exosporium proteins but were isolated from spore coat and/or exosporium fractions in other spore formers. Among these, we found orthologs of proteins involved in germination such as Gpr, SleB, or YpeB, as well as an ortholog of the DacB protein, which modifies the degree of glycan cross-linking in the cortex [39]. Finally, we also identified six proteins corresponding to orthologs of $\alpha / \beta$-SASPs, which have been implicated in spore resistance, as well as the proteins SpmA, SpmB, SpoVFA, and SpoVFB, which are involved in spore core hydration $[4,7,8,10]$.

\subsection{Proteomic Analysis of Spores Formed at Different Temperatures}

A proteomic analysis was performed on total protein extracts of spores of M. thermoacetica ATCC 39073 produced at either $45^{\circ} \mathrm{C}$ or $55^{\circ} \mathrm{C}$, which enabled the identification of a total of 1018 proteins (Tables S3 and S4). Of these, 91 were significantly differentially produced in spores formed at $45^{\circ} \mathrm{C}$ versus $55^{\circ} \mathrm{C}$ (Table S3).

Of the 62 putative spore-associated proteins identified by our in silico analysis, 24 were identified by LC-MS/MS and changes in their relative abundance between the two sporulation conditions were determined (Table 2). Based on localization data reported for other spore-forming bacteria, we found 7 putative exosporium-related proteins, 11 putative coat 
proteins, and 6 proteins that were putatively localized in the core, in the inner membrane, or had no assigned localization (Tables 1 and 2).

Table 2. Spore-associated proteins identified by proteomic analysis of Moorella thermoacetica ATCC 39073 spores produced at $55^{\circ} \mathrm{C}$ and $45^{\circ} \mathrm{C}$.

\begin{tabular}{|c|c|c|c|c|}
\hline \multirow{2}{*}{ Protein ID ${ }^{a}$} & \multirow{2}{*}{ Moorella thermoacetica Protein Identification a } & \multicolumn{2}{|c|}{ Mean Spectral Counts } & \multirow{2}{*}{$\begin{array}{l}p \text { Adjust } \\
\text { Value }\end{array}$} \\
\hline & & $55^{\circ} \mathrm{C}^{\mathrm{b}}$ & $45^{\circ} C^{b}$ & \\
\hline Q2RIR1 & Glycosyl transferase (CotSA) & $5.3 \pm 2.9$ & $0.0 \pm 0.0$ & 0.0002 \\
\hline Q2RIV7 & Stage IV sporulation protein A (SpoIVA) & $41.0 \pm 6.6$ & $21.3 \pm 11.5$ & 0.0007 \\
\hline Q2RGT7 & NADH:flavin oxidoreductase/NADH oxidase (YqiG) & $11.3 \pm 7.6^{\mathrm{c}}$ & $2.7 \pm 3.1$ & 0.0016 \\
\hline Q2RIB2 & FAD/NAD $(\mathrm{P})$-binding oxidoreductase & $53.0 \pm 4.6$ & $32.0 \pm 4.6$ & 0.0027 \\
\hline Q2RHK6 & Coat protein $\mathrm{F}^{\mathrm{d}}$ & $9.7 \pm 3.2$ & $2.3 \pm 2.1$ & 0.0045 \\
\hline Q2RM03 & Propeptide, PepSY amd peptidase M4 (YpeB) & $3.3 \pm 3.1^{\mathrm{e}}$ & $0.0 \pm 0.0$ & 0.0057 \\
\hline Q2RJL6 & Peptidase M16-like protein $(Y m x G)$ & $8.3 \pm 1.2$ & $2.3 \pm 0.6$ & 0.0190 \\
\hline Q2RH73 & Superoxide dismutase (SodF) & $2.3 \pm 2.1^{\mathrm{e}}$ & $0.0 \pm 0.0$ & 0.0275 \\
\hline Q2RIN4 & Manganese containing catalase $(\operatorname{CotJC})$ & $8.3 \pm \pm 4.7$ & $1.7 \pm 1.5$ & 0.0043 \\
\hline Q2RGX7 & Coat protein YhcQ & $6.0 \pm 1.7$ & $2.0 \pm 2.0$ & 0.0949 \\
\hline Q2RIY9 & Rubrerythrin (Rbr) & $30.0 \pm 4.5$ & $41.0 \pm 3.0$ & 0.1141 \\
\hline Q2RMG5 & 2-oxoglutarate synthase & $1.0 \pm 1.0$ & $0.0 \pm 0.0$ & 0.1841 \\
\hline Q2RGI3 & Alanine racemase (Alr) & $8.0 \pm 1.0$ & $4.0 \pm 1.0$ & 0.1907 \\
\hline Q2RJQ9 & Catalase (CotG) & $2.3 \pm 0.6$ & $0.7 \pm 1.2$ & 0.2825 \\
\hline Q2RJE9 & Amino acid $\mathrm{ABC}$ transporter substrate-binding protein (TcyA/YckK) & $4.0 \pm 1.0$ & $1.7 \pm 1.5$ & 0.2825 \\
\hline Q2RHU4 & Protein translocase subunit (YajC) & $0.7 \pm 0.6$ & $2.3 \pm 2.3$ & 0.2825 \\
\hline Q2RIN5 & Spore coat protein $(\mathrm{CotJB})$ & $0.7 \pm 1.2$ & $0.0 \pm 0.0$ & 0.2931 \\
\hline Q2RJZ7 & Small acid-soluble spore protein, alpha/beta type (SspA) & $5.0 \pm 1.0$ & $2.7 \pm 1.2$ & 0.3763 \\
\hline Q2RLT8 & Enolase (Eno) & $46.0 \pm 6.5$ & $53.0 \pm 7.2$ & 0.4941 \\
\hline Q2RHH4 & Agmatinase & $1.3 \pm 1.2$ & $2.7 \pm 1.2$ & 0.5072 \\
\hline Q2RKV7 & Hypothetical protein & $2.7 \pm 1.2$ & $3.3 \pm 1.5$ & 0.8454 \\
\hline Q2RLU7 & HAD-superfamily hydrolase subfamily IIB (YhaX) & $5.7 \pm 1.2$ & $6.3 \pm 1.2$ & 0.8787 \\
\hline Q2RHB0 & Rubrerythrin (Rbr) & $20.0 \pm 3.2$ & $21.3 \pm 2.3$ & 0.9068 \\
\hline Q2RJK6 & Ribonuclease J (RnjA) & $3.0 \pm 0.0$ & $3.3 \pm 0.6$ & 0.9207 \\
\hline
\end{tabular}

${ }^{a}$ Information from the UniProtKB database; ${ }^{b}$ Spectral counting performed on three independent biological replicates; proteins whose abundance varies significantly between $45^{\circ} \mathrm{C}$ and $55^{\circ} \mathrm{C}$ are in bold ( $p$ adjust_value < 0.05) $(n=3) ;{ }^{\mathrm{c}}$ Overlap of standard deviations; ${ }^{\mathrm{d}}$ Protein annotated as CoatF protein in the $M$. thermoacetica genome not homologous with the spore coat proteins of B. subtilis; ${ }^{\mathrm{e}}$ No spectra found in one of the three biological replicates.

Nineteen proteins were identified in both sets of spores $\left(45^{\circ} \mathrm{C}\right.$ and $\left.55^{\circ} \mathrm{C}\right)$, although nine of these were significantly less abundant (padjust_value $<0.05$ ) when spores were produced at $45{ }^{\circ} \mathrm{C}$ than at $55^{\circ} \mathrm{C}$ (Table 2). For example, the exosporium oxidoreductase protein (Q2RIB2) was quantified with an average of $32 \pm 4.6$ versus $53 \pm 4.6$ spectra, respectively. Similar patterns were detected for the coatF-like protein Q2RHK6 $(2.3 \pm 2.1$ versus $9.7 \pm 3.2$ spectra), the $\operatorname{CotJC}$ protein $(1.7 \pm 1.5$ versus $8.3 \pm 4.7$ spectra $)$, and the putative $Y m x G$ coat protein $\left(2.3 \pm 0.6\right.$ versus $8.3 \pm 1.2$ spectra in spores produced at $45^{\circ} \mathrm{C}$ and $55{ }^{\circ} \mathrm{C}$, respectively). The SpoIVA protein, which plays a role in spore coat formation, was detected with an average of $21.3 \pm 12$ versus $41 \pm 6.6$ spectra in spores produced at $45^{\circ} \mathrm{C}$ and $55^{\circ} \mathrm{C}$, respectively.

Five proteins were identified in only one sporulation temperature condition (Table 2): the proteins CotSA, YpeB, SodF, the 2-oxoglutarate synthase (Q2RMG5), and CotJB were only identified in spores produced at $55^{\circ} \mathrm{C}$. Significant differences in relative abundance were noted for CotSA, YpeB, and SodF (padjust_value $=0.0002,0.0057$ and 0.0275 , respectively), while CotJB and Q2RMG5 were present only at low levels in spores produced at $55{ }^{\circ} \mathrm{C}$, and only in one and two of the three biological replicates, respectively (Table 2). We also noticed a high variability in the relative abundance of certain proteins, such as YpeB, SodF, and the oxidoreductase YqiG, which was due to a low number of spectral counts for these proteins and the variability among replicates of protein extracts. The potential 
exosporium-related arginase (Q2RHH4) was detected with $2.7 \pm 1.2$ spectra in spores produced at $45^{\circ} \mathrm{C}$ and $1.3 \pm 1.2$ spectra in spores produced at $55^{\circ} \mathrm{C}$.

\section{Discussion}

\subsection{Coat Layers of Moorella thermoacetica Differ According to Sporulation Temperature}

Previous work by our group revealed that spores of M. thermoacetica ATCC 39073 that were produced on solid medium at $45^{\circ} \mathrm{C}$ were less resistant to wet heat and peracetic acid (PAA) than spores produced at $55^{\circ} \mathrm{C}$ [27]. Here, we investigated whether these differences in resistance could be explained by modification in the structure and/or protein composition of spores formed at different sporulation temperatures.

Using SEM and TEM, we characterized the spore surface and ultrastructure of $M$. thermoacetica spores formed at either $45^{\circ} \mathrm{C}$ or $55^{\circ} \mathrm{C}$. To our knowledge, this work produced the first SEM images describing spore surface features of $M$. thermoacetica. These SEM observations showed that the spores were spherical and had a similar shape regardless of sporulation temperature. However, spores produced at the optimal temperature $\left(55^{\circ} \mathrm{C}\right)$ were significantly bigger than spores produced at $45^{\circ} \mathrm{C}$, as previously reported for $\mathrm{B}$. weihenstephanensis [18]. At both sporulation temperatures, we observed a loose structure on the spore surface, which we assumed to be the exosporium layer.

Observations using TEM revealed that $M$. thermoacetica spores exhibited the layers classically described in bacterial endospores, namely, the cortex, the coat, and a large exosporium surrounding the spore. The presence of an exosporium was previously described for spores of $M$. thermoacetica JW/DB-2 [20]; in this strain, as for C. difficile, the exosporium is in close contact with the spore coat [20,36]. In contrast, the exosporium of $M$. thermoacetica ATCC 39073 seemed to be loose and separated from the coat layers by an interspace, as observed in B. cereus and B. anthracis [40]. Moreover, the exosporium surface of Moorella spores lacked any discernable "hair-like" projections, which have been reported in spores of $C$. difficile, C. sporogenes, B. cereus, and B. anthracis [36,37,41-43].

While the structure of the exosporium did not seem to differ between sporulation temperatures, we observed that the coat structure was indeed altered. Most of the spores produced at $55{ }^{\circ} \mathrm{C}$ exhibited a coat composed of a lamellar inner coat in direct contact with a thinner and more diffuse, but electron-dense, outer coat, while the inner and outer coat of spores produced at $45^{\circ} \mathrm{C}$ were more frequently separated by a less electrondense intermediate layer. A similar pattern was previously observed for B. subtilis spores produced at suboptimal temperature [44]. Moreover, spore coat misarrangements were more frequently observed for spores produced at $45^{\circ} \mathrm{C}$ than at $55^{\circ} \mathrm{C}$. We hypothesize that the coat may be less organized when spores are produced at temperatures closer to the lower limit possible for growth. In line with this, we also noticed that the spore core and cortex were more easily observed in spores produced at $45^{\circ} \mathrm{C}$. This observation might be due to a better permeation of staining inside spores produced at the lower temperature and, thus, certain structural differences.

Taken together, these observations might help to explain the weaker resistance properties we previously reported for $M$. thermoacetica spores produced at $45{ }^{\circ} \mathrm{C}$ [27]. In a similar way, previous research has reported that B. subtilis $\cot E$ spores that lack most coat proteins were more sensitive to glutaraldehyde, lysozyme, and oxidizing agents [11-14]. Another study showed that $B$. cereus spores lacking CotE exhibited coat defects and were less resistant to lysozyme and an oxidizing agent; interestingly, though, the mutant spores were also more resistant to heat [45].

\subsection{Identification of Spore Protein Orthologs in Moorella thermoacetica ATCC 39073}

To further investigate the differences in coat structure, we analyzed and compared the protein composition of $M$. thermoacetica spores produced at $45^{\circ} \mathrm{C}$ and $55{ }^{\circ} \mathrm{C}$. We chose to focus our data analysis on proteins that have been linked with the spore coat and exosporium in other spore formers and on proteins associated with spore resistance properties. 
As the M. thermoacetica ATCC 39073 genome is poorly annotated with respect to these proteins, we first searched for orthologs for about 200 proteins that have been previously retrieved from coat or exosporium fractions of other spore-forming bacteria. In total, about $25 \%$ of these had orthologs in $M$. thermoacetica $[34,35,37,38]$. None of the morphogenetic proteins that have been reported as components of the B. cereus or B. anthracis exosporium - such as ExsA, ExsY, CotY, BxpB, ExsM, and ExsFB [38,41,42,46]—were identified in the $M$. thermoacetica genome. We did identify putative orthologs of several C. difficile exosporium proteins, but not of the morphogenetic $\mathrm{CdeC}, \mathrm{CdeM}$, or BclA proteins (Table S2) $[37,38]$. As TEM images clearly showed the presence of a large exosporium surrounding the $M$. thermoacetica spores, we hypothesize that the Moorella exosporium proteins are different from those of other spore formers, including closely related Clostridium species. Indeed, spore surface proteins are thought to be subjected to a great deal of evolutionary pressure for adaptation to different ecological niches [41]. The in silico analysis also allowed us to identify an ortholog of the well-conserved inner coat morphogenetic protein, SpoIVA [47-50]. However, no matches were found for the morphogenetic coat proteins SafA and CotE, which are essential for the assembly of the coat basement layer and the outer coat layer, respectively, in B. subtilis and B. cereus spores [41,45]. This observation is consistent with the fact that these proteins are not conserved in Clostridia $[41,47,48,50]$. Furthermore, we found no equivalent in $M$. thermoacetica for the spore coat morphogenetic protein SipL, which plays an essential role in spore coat assembly in C. difficile by interacting with SpoIVA [51-53]. SipL is thought to be a homolog of the B. subtilis spore coat morphogenetic protein SpoVID, which does not seem to be conserved in Clostridia or M. thermoacetica $[41,48,50]$. Moreover, although it has been hypothesized that the C. difficile CotA protein could play a role in outer spore coat assembly, similarly to the Bacillus CotE protein [54], our in silico analysis did not identify any CotA ortholog in the M. thermoacetica genome.

Apart from spore coat morphogenetic proteins, few coat proteins were identified by the in silico analysis. Among the proteins known to be associated with the inner coat, we identified CotJB and CotJC, but not CotJA. In B. subtilis, these three proteins are encoded by the tricistronic operon $\cot J A-\cot J B-\cot J C$ [55]; however, a comparative genomic study showed that the CotJA, CotJB, and CotJC orthologs are not always found together [47]. Our analysis also identified a YhaX ortholog, corresponding to a spore-coat basement protein, as well as an ortholog of the C. difficile CotG catalase [54]. However, we found no ortholog of $B$. subtilis $\operatorname{Cot} G$, which has a negative effect on $\operatorname{Cot} U, \operatorname{Cot} C$ and $\operatorname{CotS}$ assembly [56]; these three coat proteins were likewise absent in the $M$. thermoacetica genome.

Several orthologs of inner membrane proteins were present in $M$. thermoacetica, including three putative spore cortex lytic enzymes (SleB) and the YpeB protein, which has been shown to be required for SleB stabilization, via protein-protein interactions, and subsequent germination of B. anthracis spores [57]. We also identified orthologs of two other widely conserved germination proteins, Gpr and YtfJ/GerW [49]. Moreover, we found two serine-type D-Ala-D-Ala carboxypeptidases that correspond to putative orthologs of DacB (the first and second BlastP hits were Q2RIR9 (moth_1058) and Q2RJL7 (moth_1357), respectively), which is involved in peptidoglycan cross-linking $[4,39,58]$. In $B$. subtilis, the $d a c B$ gene is located in an operon with $s p m A$ and $s p m B$, while in $C$. perfringens dacB is monocistronic [4]. In M. thermoacetica, SpmA and SpmB are encoded by moth_1356 and moth_1355, respectively. As the Q2RIR9 and Q2RJL7 proteins were similar, we considered them both to be potential DacB proteins. Interestingly, we identified several orthologs encoding proteins that are thought to play a role in preventing spore germination, such as the alanine racemase Alr, or that have been implicated in spore resistance, such as the coat protein SodF, which is associated with a potential resistance to oxidizing agents, and two potential exosporium-related rubrerythrins. However, as mentioned above, the CotA protein, which is associated with resistance to oxidizing chemicals in B. subtilis but is absent in Clostridia [41], was not identified here. 
We also identified orthologs for all the spore resistance-associated proteins localized in the inner spore layers, including the $\alpha / \beta$-type SASPs SspA and SspF. Several studies have shown that $\alpha / \beta$-type SASPs in Bacilli and Clostridia play a major role in protecting spore DNA against UV-C and genotoxic chemicals $[1,8,10]$. We also found orthologs of the two conserved proteins SpmA and SpmB, which play an essential role in spore core hydration $[1,3,4,39,49]$, as well as SpoVFA and SpoVFB, which are essential for DPA production. DPA chelates with $\mathrm{Ca}^{2+}$ to form Ca-DPA, which is imported into the forespore core and lowers the spore water content, thus improving its resistance properties [2]. CaDPA has been shown to play a role in spore resistance to both heat and chemicals $[5,31,59]$.

\subsection{Proteins Extracted from Moorella thermoacetica ATCC 39073 Spores Differ Based on Sporulation Temperature}

Our morphological analysis revealed that spore structure in $M$. thermoacetica, and more precisely, the arrangement of the coat layers, seemed to be modified by sporulation temperature at a temperature close to the lower limit for growth. We therefore investigated if the differences we observed in coat structure could be due to a difference in protein composition.

A proteomic analysis allowed the identification of 1018 spore proteins (Tables S3 and S4). However, despite the purification steps we carried out after spore harvesting, it is possible that spore suspensions may have contained some debris from vegetative cells, due to the low sporulation efficiency of this bacterium; indeed, an earlier report on another strain of M. thermoacetica found that only $5 \%$ of the cells formed spores [60]. For this reason, we focused only the putative spore structural or spore-associated proteins, identified in our in silico analysis.

Of the 62 spore proteins identified in the genome of M. thermoacetica ATCC 39073, 24 were detected by LC-MS/MS analysis. We found seven proteins that were potentially associated with the exosporium layer, such as the two rubrerythrins Rbr, encoded by the moth_1286 and moth_1279 loci [31], as well as a putative arginase [61], an enolase, and an alanine racemase. The protein product of the moth_1518 locus, which was identified as an ortholog of an uncharacterized exosporium protein, was significantly less abundant in spores produced at $45^{\circ} \mathrm{C}$, while the putative arginase encoded by the moth_1815 locus was slightly more abundant.

Among the 11 putative coat proteins retrieved, the coat morphogenetic protein SpoIVA appeared to be less abundant in protein extracts from spores produced at $45^{\circ} \mathrm{C}$ than at $55^{\circ} \mathrm{C}$ (padjust_value $<0.05$ ). Given that our TEM analysis found that spores produced at $45^{\circ} \mathrm{C}$ exhibited more coat misarrangement, and that SpoIVA is essential for coat formation [41], it is tempting to hypothesize that the lower amount of this protein in spores produced at $45{ }^{\circ} \mathrm{C}$ may lead to a reduced cohesion of the $M$. thermoacetica spore coat.

Four spore coat proteins were less abundant in protein extracts of spores produced at the suboptimal compared to the optimal temperature, such as the coat-F containing protein, encoded by the moth_1782 locus and the inner coat protein CotJC. Instead, CotSA and SodF were not detected in spores produced at $45^{\circ} \mathrm{C}$. In C. difficile, the superoxide dismutase SodF likely plays a role in polymerizing the spore coat protein monomers by oxidative crosslinking in the presence of $\mathrm{H}_{2} \mathrm{O}_{2}$, while CotJC might be involved in resistance to oxidative stress, although in both cases their protective role remains to be elucidated $[41,54]$. If SodF and CotJC do in fact play a protective role and are less abundant in spores produced at $45^{\circ} \mathrm{C}$ than at $55^{\circ} \mathrm{C}$, this might explain, at least partially, the lower resistance of $M$. thermoacetica spores to peracetic acid when formed at a suboptimal temperature [27].

Altogether, we report that certain proteins were relatively less abundant in spores produced at $45{ }^{\circ} \mathrm{C}$ than in those formed at $55^{\circ} \mathrm{C}$. This could be due to a true difference in abundance between spores formed at different temperatures and/or that a different structuration of spores allowed these proteins to be more readily extracted at $55^{\circ} \mathrm{C}$. Our results do not allow us to determine which hypothesis is valid, but overall, they point to modifications in $M$. thermoacetica spore coat composition and/or structure that appear to be 
based on sporulation temperature. In this, our study is in agreement with work in B. subtilis, showing that the amount of extracted outer spore coat proteins, such as $\operatorname{Cot} A, \operatorname{Cot} U, \operatorname{Cot} G$, or $\operatorname{Cot} Q$, as well as crust proteins, such as $\operatorname{Cot} X, \operatorname{Cot} Y$, and $\operatorname{Cot} Z$, varied depending on the sporulation conditions [23]. It was also shown that fewer CotA and CotS proteins were extracted from B. subtilis spores produced at a high temperature [15], while another recent study revealed that $\mathrm{Cot} G$ and $\operatorname{CotB}$ were more abundantly extracted from spores produced at $25^{\circ} \mathrm{C}$ than from spores produced at $42{ }^{\circ} \mathrm{C}$ [44].

In conclusion, we investigated the structure and protein composition of $M$. thermoacetica spores produced at optimal and low-limit growth temperatures. Using electron microscopy, we showed that spores produced at $45^{\circ} \mathrm{C}$ were smaller than those formed at $55^{\circ} \mathrm{C}$. Moreover, spores exhibited some differences in the inner coat structure depending on the sporulation temperature. We found that the spore protein composition varied between sporulation temperatures and, more precisely, that fewer spore coat proteins were extracted from spores produced at $45^{\circ} \mathrm{C}$. It is possible to hypothesize that the morphological differences observed between spores produced at $45^{\circ} \mathrm{C}$ and $55^{\circ} \mathrm{C}$ could be due to (1) a lower abundance of structural proteins in spores produced at $45^{\circ} \mathrm{C}$, leading to a more loosely arranged coat aspect; and/or (2) differences in protein cross-linking between spores produced at $45^{\circ} \mathrm{C}$ and $55^{\circ} \mathrm{C}$. The differences observed in terms of protein composition and, in particular, the lower abundance of SodF and certain structural coat proteins in spores produced at $45^{\circ} \mathrm{C}$ might be involved in the differing resistance properties of these spores to wet heat and biocides. However, more work is needed to improve the purification process for Moorella spores, as well as the extraction of insoluble spore proteins to (1) provide a more thorough characterization of $M$. thermoacetica spore proteins and those associated with specific layers (i.e., coat and exosporium); and (2) confirm the differences we noticed in spore protein composition between the two temperature conditions and highlight other potential variations. Indeed, several parameters play a role in spore resistance to chemicals and wet heat, such as DPA content, spore core dehydration, and inner-membrane fatty-acid content $[16,22,62]$. It would therefore be interesting to further characterize $M$. thermoacetica spores in order to better understand how sporulation temperature affects Moorella spore resistance, to decipher how these spores are able to exhibit such robust resistance properties.

\section{Material and Methods}

\subsection{Strain and Spore Production}

This study was performed with the Moorella thermoacetica ATCC 39073 strain. The bacteria were stored in a cryogenic preservative solution with beads (AES Chemunex, Bruz, France). Pre-cultures were performed by dropping three beads in $10 \mathrm{~mL}$ of modified deoxygenated DTB medium (mod DTB: $9 \mathrm{~g} / \mathrm{L}$ tryptone, $4 \mathrm{~g} / \mathrm{L}$ tryptose, $7 \mathrm{~g} / \mathrm{L}$ soytone, $5 \mathrm{~g} / \mathrm{L}$ yeast extract, $5 \mathrm{~g}$ /L sodium chloride, $1 \mathrm{~g} / \mathrm{L}$ potato starch, and $10 \mathrm{~g} / \mathrm{L}$ D-glucose). All components were purchased from Biokar Diagnostics, (Allonne, France) or Thermo Fisher Diagnostics (Dardilly, France). Pre-cultures were incubated at $55^{\circ} \mathrm{C}$ for 4 to 6 days in anaerobiosis with paraffin. A volume of $200 \mu \mathrm{L}$ of pre-culture was inoculated into 10-mL tubes of mod DTB that have been previously reduced in an anaerobic chamber for 24 to $48 \mathrm{~h}\left(90 \% \mathrm{~N}_{2}, 5 \% \mathrm{H}_{2}, 5 \%\right.$ $\mathrm{CO}_{2}$, Whitley A35 Workstation, Don Whitley Scientific, Bingley, UK). Anaerobiosis was maintained with paraffin and cultures were incubated either at $55^{\circ} \mathrm{C}$ for 4 to 5 days or at $45^{\circ} \mathrm{C}$ for 13 days. Sporulation was then promoted by pouring $2 \mathrm{~mL}$ of cultures onto the surface of 140-mm-diameter meat liver agar plates (MLA, Biokar Diagnostics, Allonne, France). Plates were incubated under anaerobiosis (Oxoïd ${ }^{\mathrm{TM}}$ AnaeroGen ${ }^{\mathrm{TM}}$ jars and sachets, Sigma-Aldrich, Saint-Quentin-Fallavier, France) at either $45^{\circ} \mathrm{C}$ or $55^{\circ} \mathrm{C}$. Sporulation was checked and stopped after 3 to 4 weeks of incubation; plates were incubated at room temperature for an additional week. Spores were then harvested with cold sterile water, centrifuged at $1400 \times g$ for $20 \mathrm{~min}$ at $4{ }^{\circ} \mathrm{C}$, and resuspended in sterile water. Unless otherwise stated, the suspensions were heat-treated at $100{ }^{\circ} \mathrm{C}$ for $10 \mathrm{~min}$ to inactivate the residual vegetative forms and germinated spores [27]. Spore suspensions were stored at $4{ }^{\circ} \mathrm{C}$ until use. 


\subsection{Spore Purification}

One-milliliter aliquots of heat-treated spore suspensions were briefly centrifuged at $200 \times g$ for $1 \mathrm{~min}$ at $4{ }^{\circ} \mathrm{C}$ and the supernatant was removed. The spore purification protocol, adapted from Aoyama [60], was as follows: spores were resuspended in $1 \mathrm{~mL}$ of $10 \mathrm{mM}$ Tris- $\mathrm{HCl}$ buffer $\mathrm{pH} 8.0$ containing $1.7 \mu \mathrm{g} / \mu \mathrm{L}$ lysozyme (Sigma Aldrich, Saint-Quentin Fallavier, France) and incubated overnight at $37^{\circ} \mathrm{C}$ with continuous stirring. Lysis of remaining vegetative cells was checked under a phase-contrast microscope (Leica DM750, France). Spore suspensions were washed three times in $1 \mathrm{~mL}$ of cold sterile distilled water, centrifuged at $5000 \times g$ for $10 \mathrm{~min}$ at $8{ }^{\circ} \mathrm{C}$, resuspended in $1 \mathrm{~mL}$ of $1 \% \operatorname{SDS}(v / v)$ (Sigma Aldrich, Saint-Quentin Fallavier, France), and incubated at $37^{\circ} \mathrm{C}$ for $2 \mathrm{~h}$ with continuous stirring. Spores were then washed three times in cold sterile distilled water at $5000 \times g$ for $10 \mathrm{~min}$ at $20^{\circ} \mathrm{C}$ and the presence of phase-bright spores was checked under a phase-contrast microscope. Spore suspensions were stored at $4{ }^{\circ} \mathrm{C}$ until use.

\subsection{Spore Structure Analysis}

For transmission electron microscopy (TEM), freshly harvested and non-heat-treated spores were re-suspended in $40 \mathrm{~mL}$ of cold sterile water and washed four times by centrifugation at $1400 \times g$ for $20 \mathrm{~min}$. Spores were prepared as previously described [45], except that post-fixation was performed with $1 \%$ osmium tetroxide. Four independent spore batches per sporulation temperature $\left(45^{\circ} \mathrm{C}\right.$ and $\left.55^{\circ} \mathrm{C}\right)$ were used and up to 17 spores were observed per batch.

For scanning electron microscopy (SEM), freshly harvested and non-heat-treated spore suspensions were filtered on a $0.45-\mu \mathrm{m}$ porosity membrane (Nucleopore, Whatman, Dutscher, Bernolsheim, France). Spores retained on the filter were fixed for $1 \mathrm{~h}$ at room temperature with $2.5 \%$ glutaraldehyde $(v / v)$ in a $0.1 \mathrm{M}$ sodium cacodylate buffer $(\mathrm{pH} 7.2)$ containing $1 \mathrm{mg} / \mathrm{mL}$ ruthenium red. The filter was washed three times in $0.2 \mathrm{M}$ sodium cacodylate. Spores were post-fixed for $1 \mathrm{~h}$ at room temperature with $1 \%$ osmium tetroxide. Filters were then washed several times with water and placed in 30\% ethanol. Spores were subjected to successive agitated dehydration baths containing increasing concentrations of ethanol $(50 \%, 70 \%, 90 \%$, and $100 \%)$. Next, samples were transferred into a hexamethyldisilazane (HMDS) bath until completely evaporated. Filters were pasted on a metallic support and gold plated. Observations were performed at $10 \mathrm{KV}$ (SEM; Microscope FEI-Philips XL-30, Eindhoven, The Netherlands). Four batches were used per sporulation temperature and a total of up to 35 spores was observed per batch.

\subsection{Spore Size Measurement}

To measure the diameter of spores produced at $45{ }^{\circ} \mathrm{C}$ and $55{ }^{\circ} \mathrm{C}$, SEM images were analyzed using ImageJ analysis software (v. 1.51j8, National Institutes of Health, Bethesda, MD, USA). A total of 73 and 78 spores from the four batches produced at $45^{\circ} \mathrm{C}$ and $55^{\circ} \mathrm{C}$, respectively, was measured. The normality of the data distribution and the homogeneity of variance were tested using a Shapiro-Wilk test and a Fisher test, respectively. A Student's $t$-test was performed to compare mean diameter values (Table S1). All statistical tests were conducted using XLSTAT (v. 2017.7) or utility software (Anastats Scop SARL, Rilly-surVienne, France).

\subsection{Spore Protein Extraction and Electrophoresis}

Aliquots of $1 \mathrm{~mL}$ of spore suspensions (approx. $10^{7}$ spores $/ \mathrm{mL}$, depending on the batch) were centrifuged at $5000 \times g$ for $10 \mathrm{~min}$ at $4{ }^{\circ} \mathrm{C}$. Spores were then resuspended in $1 \mathrm{~mL}$ of extraction buffer composed of $50 \mathrm{mM}$ Tris- $\mathrm{HCl}$ buffer $\mathrm{pH} 7.5,1 \mathrm{X}$ proteaseinhibiting cocktail (cOmplete ${ }^{\mathrm{TM}}$ mini Protease inhibitor cocktail EDTA-free Roche, SigmaAldrich, Saint-Quentin Fallavier, France) and 5 mM EDTA pH 8.0 (UltraPure $^{\mathrm{TM}} 0.5 \mathrm{M}$ EDTA, ThermoFisher Scientific, Villebon sur Yvette, France). Spores were lysed using 0.1-mm-diameter silica beads (MP biomedicals, Illkirch, France) in a Fast-Prep 120 machine (FastPrep ${ }^{\circledR}$ FP120 Cell Disrupter, Thermo Savant, Illkirch, France). A series of 20 to 25 runs 
of $45 \mathrm{~s}$ at the maximal speed of 6.5 were performed until spores were completely lysed, as observed under a phase-contrast microscope. Samples were placed on ice for $1 \mathrm{~min}$ between runs to prevent protein degradation by over-heating.

Proteins were quantified using a colorimetric method based on the Bradford dyebinding assay, following the manufacturer's instructions (Bio-Rad protein assay, Life Science, Marnes-la-Coquette, France). Extracted proteins were mixed with 1X Laemmli buffer (Bio-Rad, Life Science, Marnes-la-Coquette, France) to which 2.5\% $\beta$-mercaptoethanol was added, and heated at $100{ }^{\circ} \mathrm{C}$ for $10 \mathrm{~min}$. A short migration of the proteins was carried out on a $12 \%$ polyacrylamide gel using the following program: $20 \mathrm{~min}$ at $90 \mathrm{~V}$ and at $150 \mathrm{~V}$ to obtain a $5 \mathrm{mM}$ in length migration. The gel was stained with imperial blue (Imperial $^{\mathrm{TM}}$ Protein Stain, Thermo Fisher Scientific, Villebon sur Yvette, France) (Figure S3) and destained overnight in water; each lane was then cut in 3-mm squares for subsequent proteomic analysis.

\subsection{LC-MS/MS Analysis}

\subsubsection{Protein In-Gel Digestion}

Each cut piece of gel was washed for 15 min with a 1:1 mixture of acetonitrile and $100 \mathrm{mM}$ ammonium bicarbonate. The proteins contained in the gel were reduced with $10 \mathrm{mM}$ dithiothreitol (Sigma, Saint Louis, MO, USA) and alkylated with $55 \mathrm{mM}$ iodoacetamide (Sigma, Saint Louis, MO, USA) [63]. Digestion was performed in $50 \mathrm{mM}$ ammonium bicarbonate ( $\mathrm{pH} 8.0)$ and the quantity of modified trypsin (sequencing grade Promega, Madison, WI, USA) was adjusted in order to have an enzyme-to-protein ratio $(w / w)$ equal to $1: 50$ in each sample. Digestion was carried out overnight at $37^{\circ} \mathrm{C}$ and the supernatant was conserved. Peptides were extracted with $0.5 \%$ trifluoroacetic acid (TFA) in water/acetonitrile $(v / v)$. Supernatants and extracted tryptic peptides were dried and resuspended at a concentration of $40 \mathrm{ng} / \mu \mathrm{L}$ in $0.08 \%(v / v)$ TFA and $2 \%(v / v)$ acetonitrile. We then injected $160 \mathrm{ng}$ (according to the protein concentration measured prior to digestion) in the LC-MS/MS apparatus.

Peptide samples were solubilized in a buffer of $2 \% \mathrm{CH}_{3} \mathrm{CN}, 0.08 \%$ TFA. Liquid chromatography was performed on a NanoLC Ultra system (Eksigent, AB SCIEX, Dublin, CA,

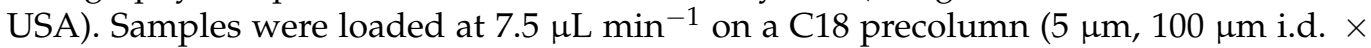
$2 \mathrm{~cm}$ length; NanoSeparations, Nieuwkoop, The Netherlands) connected to a separating Thermo PepMap 2 C18 column $(2 \mu \mathrm{m}, 75 \mu \mathrm{m}$ i.d. $\times 25 \mathrm{~cm}$ length, Thermo Fisher Scientific, Waltham, MA, USA). Solvent A was $0.1 \%$ formic acid in water and solvent B was $0.1 \%$ formic acid in ACN. Peptide separation was achieved using a linear gradient from $5 \%$ to $30 \%$ of solvent B for $75 \mathrm{~min}$ at $300 \mathrm{~nL} \mathrm{~min}^{-1}$. Including the regeneration and the equilibration steps, a single run took 93 min. Eluted peptides were analyzed with a Q Exactive PLUS mass spectrometer (Thermo Fisher Scientific, San Jose, CA, USA) using a nanoelectrospray interface. Ionization was performed with a $1.3 \mathrm{kV}$ spray voltage applied to an uncoated capillary probe $(10 \mu \mathrm{m}$ i.d., New Objective, Littleton, MA, USA). Acquisition was performed in data-dependent mode and fragmentation occurred in HCD (Higher energy collisional dissociation). This included a full MS scan covering a mass-to-charge ratio $(\mathrm{m} / \mathrm{z})$ of 300 to 1400 with a resolution of 70,000 and an MS/MS step (normalized collision energy, 27\%; resolution, 17,500). Dynamic exclusion was set to $40 \mathrm{~s}$

The mass spectrometry proteomics raw data were deposited in the PRIDE partner repository [64], as a ProteomeXchange dataset [65], with the identifier PXD029621 (http: / / www.ebi.ac.uk/pride/archive/projects/PXD029621, accessed on 8 November 2021).

\subsubsection{Identification and Quantification of Proteins}

Data were converted to mzXML format using MS convert (ProteoWizard v 3.0.8934). Proteins were identified using X!Tandem v.2015.04.01.1 [66] by matching peptides against the UniprotKB Moorella thermoacetica ATCC 39073 database containing 2452 entries (http: / / www.uni-prot.org/proteomes/UP000007053, accessed on 29 September 2021). Proteins were filtered and grouped using the X!TandemPipeline software v.3.4.2 [67], open-source 
software developed by PAPPSO (http:/ / pappso.inrae.fr/bioinfo/xtandempipeline/, accessed on 29 September 2021). To eliminate the spectra created by the contaminants, data were also compared to a contaminant database.

Proteome identification was carried out with a precursor mass tolerance of $10 \mathrm{ppm}$ and a fragment mass tolerance of $0.02 \mathrm{Da}$. Enzymatic cleavage rules were set to trypsin digestion ("after Arg and Lys, unless Pro follows directly after") and no semi-enzymatic cleavage rules were allowed. The fix modification was set to cysteine carbamidomethylation and methionine oxidation was considered as a potential modification. In a second pass, $\mathrm{N}$-terminal acetylation was added as another potential modification, but all other previous settings were retained. The identified proteins were filtered as follows: (1) peptide Evalue $<0.05$ with a minimum of 2 peptides per protein; and (2) a protein E-value of $<10^{-4}$. Table S3 contains information on the number of spectra of at least 2, in at least one condition, for the $45{ }^{\circ} \mathrm{C}$ and the $55{ }^{\circ} \mathrm{C}$ samples and FDR peptides $=0.02 \%$ and FDR proteins $=0.09 \%$. Table S4 reports peptides corresponding to proteins identified in Table S3.

Protein abundance values were calculated using spectral counts from three independent biological replicates. We used a rough semi-quantitative method, which allows us to detect large variations in abundance, including presence/absence variations [68-70]. In addition, normalization was done according to the method

$$
n \times\left(\frac{M s}{T s}\right)
$$

where $n$ refers to the number of spectra identified per protein in the sample, Ms refers to the mean sum of spectra identified for each sample, and Ts refers to the total number of spectra per sample.

MassChroqR (version 0.3.7), an R toolbox developed by the PAPPSO platform (http: / / pappso.inrae.fr /, accessed on 29 September 2021), was used to check the quality of the data and perform statistical analysis on the proteomic data. The significance of variation was determined by an ANOVA (analysis of variance) test in all analyses. The obtained $p$-values were adjusted for multiple testing by the Benjamini-Hochberg approach [71]. The padjust_values obtained from the ANOVA for the proteomic data were considered significant below a value of 0.05 in SC.

\subsection{Identification of Spore-Associated Proteins}

Using the Blast-P tool (https:/ / blast.ncbi.nlm.nih.gov/Blast.cgi, accessed on 29 September 2021), the amino-acid sequences of the spore-associated proteins from several sporeforming species $[34,35,37,38,72]$ were used to query the M. thermoacetica ATCC 39073 genome. To define a "hit", we considered several criteria: \% of identity or homology, \% of protein coverage, and a minimal E-value of $2.00 \times 10^{-6}$.

Supplementary Materials: The following supporting information can be downloaded at: https: //www.mdpi.com/article/10.3390/ijms23010550/s1.

Author Contributions: Conceptualization, V.B., T.M. and S.P.; methodology, T.M., F.F., I.B. and E.H.; validation, T.M., V.B. and S.P.; formal analysis, T.M. and S.P.; investigation, T.M., F.F. and I.B.; resources, T.M. and F.F.; data curation, T.M., E.H., C.H. and S.P.; writing—original draft preparation, T.M., S.P. and V.B.; writing-review and editing, T.M., S.P., I.B., F.F., E.H., C.H. and V.B.; visualization, T.M., I.B., V.B. and S.P.; supervision, S.P. and V.B.; project administration, S.P. and V.B.; funding acquisition, S.P. All authors have read and agreed to the published version of the manuscript.

Funding: Tiffany Malleck received financial support for her PhD thesis from the Association Nationale de la Recherche et de la Technologie (ANRT), France and FranceAgriMer (FAM).

Institutional Review Board Statement: Not applicable.

Informed Consent Statement: Not applicable. 
Data Availability Statement: The raw LC-MS/MS data were deposited in the PRIDE partner repository as a ProteomeXchange dataset (PXD029621).

Acknowledgments: The authors thank Isabelle Martin-Verstraete, Mohammed Jebbar and Frédéric Carlin for helpful discussions and Bénédicte Doublet for providing help with protein extraction. Part of this work was supported by the microscopy facilities of Platform 3A, funded by the European Regional Development Fund, the French Ministry of Research, Higher Education and Innovation, the Provence-Alpes-Côte d'Azur region, the Departmental Council of Vaucluse and the Urban Community of Avignon.

Conflicts of Interest: The authors declare no conflict of interest. The funders had no role in the design of the study; in the collection, analyses, or interpretation of data; in the writing of the manuscript, or in the decision to publish the results.

\section{References}

1. Setlow, P. Spore Resistance Properties. Microbiol. Spectr. 2014, 2, 201-215. [CrossRef] [PubMed]

2. Leggett, M.J.; McDonnell, G.; Denyer, S.; Setlow, S.; Maillard, J.-Y. Bacterial spore structures and their protective role in biocide resistance. J. Appl. Microbiol. 2012, 113, 485-498. [CrossRef] [PubMed]

3. Popham, D.L.; Sengupta, S.; Setlow, P. Heat, hydrogen peroxide, and UV resistance of Bacillus subtilis spores with increased core water content and with or without major DNA-binding proteins. Appl. Environ. Microbiol. 1995, 61, 3633-3638. [CrossRef] [PubMed]

4. $\quad$ Paredes-Sabja, D.; Raju, D.; Torres, J.A.; Sarker, M.R. Role of small, acid-soluble spore proteins in the resistance of Clostridium perfringens spores to chemicals. Int. J. Food Microbiol. 2008, 122, 333-335. [CrossRef] [PubMed]

5. Setlow, P. Spores of Bacillus subtilis: Their resistance to and killing by radiation, heat and chemicals. J. Appl. Microbiol. 2006, 101, 514-525. [CrossRef] [PubMed]

6. Setlow, P.; Christie, G. What's new and notable in bacterial spore killing! World J. Microbiol. Biotechnol. 2021, 37, 144. [CrossRef] [PubMed]

7. Tennen, R.; Setlow, B.; Davis, K.; Loshon, C.; Setlow, P. Mechanisms of killing of spores of Bacillus subtilis by iodine, glutaraldehyde and nitrous acid. J. Appl. Microbiol. 2000, 89, 330-338. [CrossRef]

8. Raju, D.; Setlow, P.; Sarker, M.R. Antisense-RNA-Mediated Decreased Synthesis of Small, Acid-Soluble Spore Proteins Leads to Decreased Resistance of Clostridium perfringens Spores to Moist Heat and UV Radiation. Appl. Environ. Microbiol. 2007, 73, 2048-2053. [CrossRef]

9. Setlow, P. I will survive: DNA protection in bacterial spores. Trends Microbiol. 2007, 15, 172-180. [CrossRef]

10. Paredes-Sabja, D.; Bond, C.; Carman, R.J.; Setlow, P.; Sarker, M.R. Germination of spores of Clostridium difficile strains, including isolates from a hospital outbreak of Clostridium difficile-associated disease (CDAD). Microbiology 2008, 154, 2241-2250. [CrossRef]

11. Riesenman, P.J.; Nicholson, W.L. Role of the Spore Coat Layers in Bacillus subtilis Spore Resistance to Hydrogen Peroxide, Artificial UV-C, UV-B, and Solar UV Radiation. Appl. Environ. Microbiol. 2000, 66, 620-626. [CrossRef]

12. Ghosh, S.; Setlow, B.; Wahome, P.G.; Cowan, A.E.; Plomp, M.; Malkin, A.J.; Setlow, P. Characterization of Spores of Bacillus subtilis That Lack Most Coat Layers. J. Bacteriol. 2008, 190, 6741-6748. [CrossRef]

13. Leggett, M.J.; Schwarz, J.S.; Burke, P.A.; McDonnell, G.; Denyer, S.P.; Maillard, J.-Y. Resistance to and killing by the sporicidal microbicide peracetic acid. J. Antimicrob. Chemother. 2014, 70, 773-779. [CrossRef]

14. Leggett, M.J.; Schwarz, J.S.; Burke, P.A.; McDonnell, G.; Denyer, S.P.; Maillard, J.-Y. Mechanism of Sporicidal Activity for the Synergistic Combination of Peracetic Acid and Hydrogen Peroxide. Appl. Environ. Microbiol. 2016, 82, 1035-1039. [CrossRef]

15. Melly, E.; Genest, P.; Gilmore, M.; Little, S.; Popham, D.; Driks, A.; Setlow, P. Analysis of the properties of spores of Bacillus subtilis prepared at different temperatures. J. Appl. Microbiol. 2002, 92, 1105-1115. [CrossRef]

16. Planchon, S.; Dargaignaratz, C.; Levy, C.; Ginies, C.; Broussolle, V.; Carlin, F. Spores of Bacillus cereus strain KBAB4 produced at $10^{\circ} \mathrm{C}$ and $30^{\circ} \mathrm{C}$ display variations in their properties. Food Microbiol. 2011, 28, 291-297. [CrossRef]

17. Baweja, R.B.; Zaman, M.S.; Mattoo, A.R.; Sharma, K.; Tripathi, V.; Aggarwal, A.; Dubey, G.P.; Kurupati, R.K.; Ganguli, M.; Chaudhury, N.K.; et al. Properties of Bacillus anthracis spores prepared under various environmental conditions. Arch. Microbiol. 2007, 189, 71-79. [CrossRef]

18. Garcia, D.; van der Voort, M.; Abee, T. Comparative analysis of Bacillus weihenstephanensis KBAB4 spores obtained at different temperatures. Int. J. Food Microbiol. 2010, 140, 146-153. [CrossRef]

19. Mtimet, N.; Trunet, C.; Mathot, A.-G.; Venaille, L.; Leguérinel, I.; Coroller, L.; Couvert, O. Modeling the behavior of Geobacillus stearothermophilus ATCC 12980 throughout its life cycle as vegetative cells or spores using growth boundaries. Food Microbiol. 2015, 48, 153-162. [CrossRef]

20. Byrer, D.E.; Rainey, F.A.; Wiegel, J. Novel strains of Moorella thermoacetica form unusually heat-resistant spores. Arch. Microbiol. 2000, 174, 334-339. [CrossRef]

21. Baril, E.; Coroller, L.; Couvert, O.; El Jabri, M.; Leguerinel, I.; Postollec, F.; Boulais, C.; Carlin, F.; Mafart, P. Sporulation boundaries and spore formation kinetics of Bacillus spp. as a function of temperature, $\mathrm{pH}$ and aw. Food Microbiol. 2012, 32, 79-86. [CrossRef] 
22. Rose, R.; Setlow, B.; Monroe, A.; Mallozzi, M.; Driks, A.; Setlow, P. Comparison of the properties of Bacillus subtilis spores made in liquid or on agar plates. J. Appl. Microbiol. 2007, 103, 691-699. [CrossRef]

23. Abhyankar, W.R.; Kamphorst, K.; Swarge, B.N.; Van Veen, H.; van der Wel, N.; Brul, S.; de Koster, C.; De Koning, L.J. The Influence of Sporulation Conditions on the Spore Coat Protein Composition of Bacillus subtilis Spores. Front. Microbiol. 2016, 7, 1636. [CrossRef]

24. Bressuire-Isoard, C.; Broussolle, V.; Carlin, F. Sporulation environment influences spore properties in Bacillus: Evidence and insights on underlying molecular and physiological mechanisms. FEMS Microbiol. Rev. 2018, 42, 614-626. [CrossRef]

25. André, S.; Vallaeys, T.; Planchon, S. Spore-forming bacteria responsible for food spoilage. Res. Microbiol. 2017, 168, 379-387. [CrossRef]

26. Collins, M.D.; Lawson, P.A.; Willems, A.; Córdoba, J.J.; Fernandez-Garayzabal, J.F.; Garcia, P.; Cai, J.; Hippe, H.; Farrow, J.A.E. The Phylogeny of the Genus Clostridium: Proposal of Five New Genera and Eleven New Species Combinations. Int. J. Syst. Bacteriol. 1994, 44, 812-826. [CrossRef]

27. Malleck, T.; Daufouy, G.; André, S.; Broussolle, V.; Planchon, S. Temperature impacts the sporulation capacities and spore resistance of Moorella thermoacetica. Food Microbiol. 2018, 73, 334-341. [CrossRef]

28. Pierce, E.; Xie, G.; Barabote, R.D.; Saunders, E.; Han, C.S.; Detter, J.C.; Richardson, P.; Brettin, T.S.; Das, A.; Ljungdahl, L.G.; et al. The complete genome sequence of Moorella thermoacetica (f. Clostridium thermoaceticum). Environ. Microbiol. 2008, 10, $2550-2573$. [CrossRef]

29. Antunes, L.C.; Poppleton, D.; Klingl, A.; Criscuolo, A.; Dupuy, B.; Brochier-Armanet, C.; Beloin, C.; Gribaldo, S. Phylogenomic analysis supports the ancestral presence of LPS-outer membranes in the Firmicutes. eLife 2016, 5, e14589. [CrossRef]

30. Das, A.; Coulter, E.D.; Kurtz, D.M.; Ljungdahl, L.G. Five-Gene Cluster in Clostridium thermoaceticum Consisting of Two Divergent Operons Encoding Rubredoxin Oxidoreductase- Rubredoxin and Rubrerythrin-Type A Flavoprotein-High-Molecular-Weight Rubredoxin. J. Bacteriol. 2001, 183, 1560-1567. [CrossRef]

31. Gil, F.; Lagos-Moraga, S.; Calderón-Romero, P.; Pizarro-Guajardo, M.; Paredes-Sabja, D. Updates on Clostridium difficile spore biology. Anaerobe 2017, 45, 3-9. [CrossRef] [PubMed]

32. Takamatsu, H.; Imamura, A.; Kodama, T.; Asai, K.; Ogasawara, N.; Watabe, K. The yabG gene of Bacillus subtilis encodes a sporulation specific protease which is involved in the processing of several spore coat proteins. FEMS Microbiol. Lett. 2000, 192, 33-38. [CrossRef] [PubMed]

33. Boonstra, M.; Schaffer, M.; Sousa, J.; Morawska, L.; Holsappel, S.; Hildebrandt, P.; Sappa, P.K.; Rath, H.; de Jong, A.; Lalk, M.; et al. Analyses of competent and non-competent subpopulations of Bacillus subtilis reveal $y h f W, y h x C$ and ncRNAs as novel players in competence. Environ. Microbiol. 2020, 22, 2312-2328. [CrossRef] [PubMed]

34. Abhyankar, W.; Ter Beek, A.; Dekker, H.; Kort, R.; Brul, S.; de Koster, C.G. Gel-free proteomic identification of the Bacillus subtilis insoluble spore coat protein fraction. Proteomics 2011, 11, 4541-4550. [CrossRef]

35. Abhyankar, W.; Hossain, A.H.; Djajasaputra, A.; Permpoonpattana, P.; Ter Beek, A.; Dekker, H.L.; Cutting, S.M.; Brul, S.; de Koning, L.J.; de Koster, C.G. In Pursuit of Protein Targets: Proteomic Characterization of Bacterial Spore Outer Layers. J. Proteome Res. 2013, 12, 4507-4521. [CrossRef]

36. Paredes-Sabja, D.; Shen, A.; Sorg, J. Clostridium difficile spore biology: Sporulation, germination, and spore structural proteins. Trends Microbiol. 2014, 22, 406-416. [CrossRef]

37. Díaz-González, F.; Milano, M.; Olguin-Araneda, V.; Pizarro-Cerda, J.; Castro-Córdova, P.; Tzeng, S.-C.; Maier, C.S.; Sarker, M.R.; Paredes-Sabja, D. Protein composition of the outermost exosporium-like layer of Clostridium difficile 630 spores. J. Proteom. 2015, 123, 1-13. [CrossRef]

38. Stewart, G.C. The Exosporium Layer of Bacterial Spores: A Connection to the Environment and the Infected Host. Microbiol. Mol. Biol. Rev. 2015, 79, 437-457. [CrossRef]

39. Popham, D.L.; Illades-Aguiar, B.; Setlow, P. The Bacillus subtilis dacB gene, encoding penicillin-binding protein $5 *$, is part of a three-gene operon required for proper spore cortex synthesis and spore core dehydration. J. Bacteriol. 1995, 177, 4721-4729. [CrossRef]

40. Driks, A.; Eichenberger, P. The Spore Coat. Microbiol. Spectr. 2016, 4, 179-200. [CrossRef]

41. Henriques, A.O.; Moran, J.C.P. Structure, Assembly, and Function of the Spore Surface Layers. Annu. Rev. Microbiol. 2007, 61, 555-588. [CrossRef]

42. Fazzini, M.M.; Schuch, R.; Fischetti, V.A. A Novel Spore Protein, ExsM, Regulates Formation of the Exosporium in Bacillus cereus and Bacillus anthracis and Affects Spore Size and Shape. J. Bacteriol. 2010, 192, 4012-4021. [CrossRef]

43. Janganan, T.K.; Mullin, N.; Tzokov, S.B.; Stringer, S.; Fagan, R.P.; Hobbs, J.K.; Moir, A.; Bullough, P.A. Characterization of the spore surface and exosporium proteins of Clostridium sporogenes; implications for Clostridium botulinum group I strains. Food Microbiol. 2016, 59, 205-212. [CrossRef]

44. Isticato, R.; Lanzilli, M.; Petrillo, C.; Donadio, G.; Baccigalupi, L.; Ricca, E. Bacillus subtilis builds structurally and functionally different spores in response to the temperature of growth. Environ. Microbiol. 2020, 22, 170-182. [CrossRef]

45. Bressuire-Isoard, C.; Bornard, I.; Henriques, A.; Carlin, F.; Broussolle, V. Sporulation Temperature Reveals a Requirement for CotE in the Assembly of both the Coat and Exosporium Layers of Bacillus cereus Spores. Appl. Environ. Microbiol. 2016, 82, 232-243. [CrossRef] 
46. Johnson, M.J.; Todd, S.J.; Ball, D.A.; Shepherd, A.M.; Sylvestre, P.; Moir, A. ExsY and CotY Are Required for the Correct Assembly of the Exosporium and Spore Coat of Bacillus cereus. J. Bacteriol. 2006, 188, 7905-7913. [CrossRef]

47. De Hoon, M.J.; Eichenberger, P.; Vitkup, D. Hierarchical Evolution of the Bacterial Sporulation Network. Curr. Biol. 2010, 20, R735-R745. [CrossRef]

48. Galperin, M.Y.; Mekhedov, S.L.; Puigbo, P.; Smirnov, S.; Wolf, Y.I.; Rigden, D.J. Genomic determinants of sporulation in Bacilli and Clostridia: Towards the minimal set of sporulation-specific genes. Environ. Microbiol. 2012, 14, 2870-2890. [CrossRef]

49. Abecasis, A.B.; Serrano, M.; Alves, R.; Quintais, L.; Pereira-Leal, J.B.; Henriques, A. A Genomic Signature and the Identification of New Sporulation Genes. J. Bacteriol. 2013, 195, 2101-2115. [CrossRef]

50. Ramos-Silva, P.; Serrano, M.; O Henriques, A. From Root to Tips: Sporulation Evolution and Specialization in Bacillus subtilis and the Intestinal Pathogen Clostridioides difficile. Mol. Biol. Evol. 2019, 36, 2714-2736. [CrossRef]

51. Putnam, E.; Nock, A.M.; Lawley, T.D.; Shen, A. SpoIVA and SipL Are Clostridium difficile Spore Morphogenetic Proteins. J. Bacteriol. 2013, 195, 1214-1225. [CrossRef] [PubMed]

52. Touchette, M.H.; de la Puebla, H.B.; Ravichandran, P.; Shen, A. SpoIVA-SipL Complex Formation Is Essential for Clostridioides difficile Spore Assembly. J. Bacteriol. 2019, 201, e00042-19. [CrossRef] [PubMed]

53. De la Puebla, H.B.; Giacalone, D.; Cooper, A.; Shen, A. Role of SpoIVA ATPase Motifs during Clostridioides difficile Sporulation. J. Bacteriol. 2020, 202, e00387-20. [CrossRef]

54. Permpoonpattana, P.; Phetcharaburanin, J.; Mikelsone, A.; Dembek, M.; Tan, S.; Brisson, M.-C.; La Ragione, R.; Brisson, A.R.; Fairweather, N.; Hong, H.A.; et al. Functional Characterization of Clostridium difficile Spore Coat Proteins. J. Bacteriol. 2013, 195, 1492-1503. [CrossRef] [PubMed]

55. Henriques, A.; Beall, B.W.; Roland, K.; Moran, C.P. Characterization of cotJ, a sigma E-controlled operon affecting the polypeptide composition of the coat of Bacillus subtilis spores. J. Bacteriol. 1995, 177, 3394-3406. [CrossRef] [PubMed]

56. Saggese, A.; Isticato, R.; Cangiano, G.; Ricca, E.; Baccigalupi, L. CotG-Like Modular Proteins Are Common among Spore-Forming Bacilli. J. Bacteriol. 2016, 198, 1513-1520. [CrossRef] [PubMed]

57. Sayer, C.V.; Popham, D.L. YpeB dimerization may be required to stabilize SleB for effective germination of Bacillus anthracis spores. BMC Microbiol. 2019, 19, 1-9. [CrossRef] [PubMed]

58. Zhang, P.; Thomas, S.; Li, Y.-Q.; Setlow, P. Effects of Cortex Peptidoglycan Structure and Cortex Hydrolysis on the Kinetics of $\mathrm{Ca}^{2+}$-Dipicolinic Acid Release during Bacillus subtilis Spore Germination. J. Bacteriol. 2012, 194, 646-652. [CrossRef]

59. Paredes-Sabja, D.; Sarker, N.; Setlow, B.; Setlow, P.; Sarker, M.R. Roles of DacB and Spm Proteins in Clostridium perfringens Spore Resistance to Moist Heat, Chemicals, and UV Radiation. Appl. Environ. Microbiol. 2008, 74, 3730-3738. [CrossRef]

60. Aoyama, Y. Germination Behavior of Moorella Thermoacetica Spores; Toyo Food Research Institute: Tokyo, Japan, $2014 ;$;p. 49-54.

61. Weaver, J.; Kang, T.J.; Raines, K.W.; Cao, G.-L.; Hibbs, S.; Tsai, P.; Baillie, L.; Rosen, G.M.; Cross, A.S. Protective Role of Bacillus anthracis Exosporium in Macrophage-Mediated Killing by Nitric Oxide. Infect. Immun. 2007, 75, 3894-3901. [CrossRef]

62. Jamroskovic, J.; Chromikova, Z.; List, C.; Bartova, B.; Barak, I.; Bernier-Latmani, R. Variability in DPA and Calcium Content in the Spores of Clostridium Species. Front. Microbiol. 2016, 7, 1791. [CrossRef]

63. Shevchenko, A.; Wilm, M.; Vorm, O.; Mann, M. Mass Spectrometric Sequencing of Proteins from Silver-Stained Polyacrylamide Gels. Anal. Chem. 1996, 68, 850-858. [CrossRef]

64. Perez-Riverol, Y.; Csordas, A.; Bai, J.; Bernal-Llinares, M.; Hewapathirana, S.; Kundu, D.J.; Inuganti, A.; Griss, J.; Mayer, G.; Eisenacher, M.; et al. The PRIDE database and related tools and resources in 2019: Improving support for quantification data. Nucleic Acids Res. 2019, 47, D442-D450. [CrossRef]

65. Deutsch, E.W.; Bandeira, N.; Sharma, V.; Perez-Riverol, Y.; Carver, J.J.; Kundu, D.J.; García-Seisdedos, D.; Jarnuczak, A.F.; Hewapathirana, S.; Pullman, B.S.; et al. The ProteomeXchange consortium in 2020: Enabling 'big data' approaches in proteomics. Nucleic Acids Res. 2020, 48, D1145-D1152. [CrossRef]

66. Craig, R.; Beavis, R.C. TANDEM: Matching proteins with tandem mass spectra. Bioinformatics 2004, 20, 1466-1467. [CrossRef]

67. Langella, O.; Valot, B.; Balliau, T.; Blein-Nicolas, M.; Bonhomme, L.; Zivy, M. X!TandemPipeline: A Tool to Manage Sequence Redundancy for Protein Inference and Phosphosite Identification. J. Proteome Res. 2017, 16, 494-503. [CrossRef]

68. Carvalho, P.; Hewel, J.; Barbosa, V.; Iii, J.Y. Identifying differences in protein expression levels by spectral counting and feature selection. Genet. Mol. Res. 2008, 7, 342-356. [CrossRef]

69. Lundgren, D.H.; Hwang, S.; Wu, L.; Han, D.K. Role of spectral counting in quantitative proteomics. Expert Rev. Proteom. 2010, 7, 39-53. [CrossRef]

70. Usaite, R.; Wohlschlegel, J.; Venable, J.D.; Park, S.K.; Nielsen, J.; Olsson, L.; Iii, J.R.Y. Characterization of Global Yeast Quantitative Proteome Data Generated from the Wild-Type and Glucose RepressionSaccharomyces cerevisiaeStrains: The Comparison of Two Quantitative Methods. J. Proteome Res. 2008, 7, 266-275. [CrossRef]

71. Benjamini, Y.; Hochberg, Y. Controlling the False Discovery Rate: A Practical and Powerful Approach to Multiple Testing. J. R. Stat. Soc. Ser. B Methodol. 1995, 57, 289-300. [CrossRef]

72. Xiao, Y.; van Hijum, S.; Abee, T.; Wells-Bennik, M.H.J. Genome-Wide Transcriptional Profiling of Clostridium perfringens SM101 during Sporulation Extends the Core of Putative Sporulation Genes and Genes Determining Spore Properties and Germination Characteristics. PLoS ONE 2015, 10, e0127036. [CrossRef] 